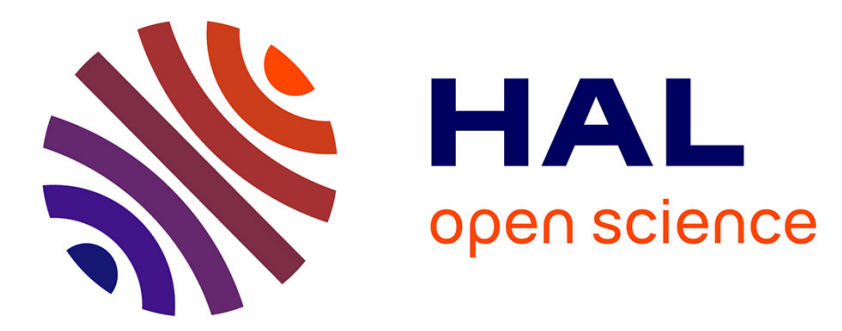

\title{
Review of Mycobacterium avium subsp. paratuberculosis antigen candidates with diagnostic potential
}

Heidi Mikkelsen, Claus Aagaard, Søren Saxmose Nielsen, Gregers Jungersen

\section{- To cite this version:}

Heidi Mikkelsen, Claus Aagaard, Søren Saxmose Nielsen, Gregers Jungersen. Review of Mycobacterium avium subsp. paratuberculosis antigen candidates with diagnostic potential. Veterinary Microbiology, 2011, 152 (1-2), pp.1. 10.1016/j.vetmic.2011.03.006 . hal-00719077

\section{HAL Id: hal-00719077 \\ https://hal.science/hal-00719077}

Submitted on 19 Jul 2012

HAL is a multi-disciplinary open access archive for the deposit and dissemination of scientific research documents, whether they are published or not. The documents may come from teaching and research institutions in France or abroad, or from public or private research centers.
L'archive ouverte pluridisciplinaire HAL, est destinée au dépôt et à la diffusion de documents scientifiques de niveau recherche, publiés ou non, émanant des établissements d'enseignement et de recherche français ou étrangers, des laboratoires publics ou privés. 


\section{Accepted Manuscript}

Title: Review of Mycobacterium avium subsp.

paratuberculosis antigen candidates with diagnostic potential

Authors: Heidi Mikkelsen, Claus Aagaard, Søren Saxmose

Nielsen, Gregers Jungersen

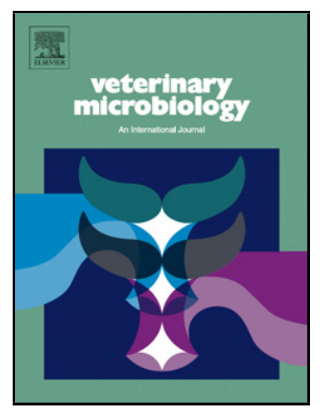

PII:

S0378-1135(11)00144-1

DOI: doi:10.1016/j.vetmic.2011.03.006

Reference: VETMIC 5229

To appear in: $\quad$ VETMIC

Received date: $\quad$ 27-10-2009

Revised date: 2-3-2011

Accepted date: $\quad$ 10-3-2011

Please cite this article as: Mikkelsen, H., Aagaard, C., Nielsen, S.S., Jungersen, G., Review of Mycobacterium avium subsp. paratuberculosis antigen candidates with diagnostic potential, Veterinary Microbiology (2010), doi:10.1016/j.vetmic.2011.03.006

This is a PDF file of an unedited manuscript that has been accepted for publication. As a service to our customers we are providing this early version of the manuscript. The manuscript will undergo copyediting, typesetting, and review of the resulting proof before it is published in its final form. Please note that during the production process errors may be discovered which could affect the content, and all legal disclaimers that apply to the journal pertain. 
3

4

5

$6 \quad{ }^{1}$ Adaptive Immunology and Parasitology, National Veterinary Institute, Technical University of

7 Denmark, Bülowsvej 27, 1790 Copenhagen, Denmark; ${ }^{2}$ Department of Large Animal Sciences,

8 Faculty of Life Sciences, University of Copenhagen, Grønnegårdsvej 8, 1870 Frederiksberg C,

9 Denmark; ${ }^{3}$ Statens Serum Institut, Department of Infectious Disease Immunology, Artillerivej 5, 10

11

12

13

14

15

\section{Review of Mycobacterium avium subsp. paratuberculosis antigen candidates} with diagnostic potential

(1)

$$
\text { Heidi Mikkelsen }^{1,2} \text {, Claus Aagaard }{ }^{3} \text {, Søren Saxmose Nielsen }{ }^{2} \text { and Gregers Jungersen }{ }^{1}
$$

$(0$

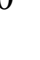

1

$$
\text { Corresponding author: Gregers Jungersen, Adaptive Immunology and Parasitology, National }
$$
Veterinary Institute, Technical University of Denmark, Bülowsvej 27, 1790 Copenhagen, Denmark, 4 e-mail: grju@vet.dtu.dk, phone +45358862 34. 
15

16

17

18

19

\section{Abstract}

Mycobacterium avium subsp. paratuberculosis (MAP) is a slow growing bacterium that can infect ruminants and remain latent for years without development of any clinical signs or disease. Diagnosis is often based on detection of MAP antibodies in milk or serum samples or culture of bacteria from faeces; however, these diagnostic tools are often not applicable until years after infection. Detection of MAP specific cell-mediated immune (CMI) responses can serve as an alternative and be implemented in a diagnostic tool. CMI responses can be measured at an early stage of infection, prior to development of antibodies and shedding of detectable amounts of MAP. At present, available diagnostic assays are limited by the lack of MAP specific antigens included in these assays resulting in poor specificity. The objective of this review is to provide a systematic overview of diagnostic MAP antigen candidates described to date with special emphasis on antigen candidates tested for CMI responses. Relevant information on 115 different MAP antigens was systematically extracted from literature and summarized in 6 tables of CMI antigens, secreted antigens, cell wall and membrane antigens, lipoprotein antigens, heat shock antigens and hypothetical antigens. Strategies for evaluation of novel antigen candidates are discussed critically. Relatively few of the described antigens were evaluated for their use in CMI based diagnostic assays and so far, no obvious candidate has been identified for this application. Most of the novel diagnostic candidates were evaluated in few animals and it is recommended that an appropriate sample size is included for evaluation of antigen candidates in future studies.

\section{Key words: paratuberculosis, antigen, diagnostic antigens}




\section{Introduction}

Mycobacterium avium subsp. paratuberculosis (MAP) is the causative agent of paratuberculosis in ruminants. MAP is part of the large and diverse Mycobacterium family that is defined by their acidfast properties, mycolic acid-containing cell walls, and high genomic $\mathrm{C}+\mathrm{G}$ content $(61-71 \%)$. The family currently counts more than 130 established and validated species and subspecies (Turenne et al., 2007). Besides ruminants, MAP can infect a large range of host species including birds, rabbits, foxes and badgers (Beard et al., 2001). Infection of dairy cattle leads to economic losses because of reduced milk yield, premature culling and reduced slaughter value (Ott et al., 1999). Cattle are most susceptible to infection as calves where they are infected while still in the uterus or by ingestion of bacteria through milk, colostrum or faecal matter (Chiodini et al., 1984; Sweeney, 1996).

Development of a cell-mediated immune (CMI) response is essential to the host in defence against intracellular MAP and is elicited at an early stage of infection before antibodies are detected. As the disease progress from subclinical to clinical, the CMI response wanes and is replaced by a strong humoral immune response characterised by antibody formation (Chiodini, 1996; Stabel, 2000). Antibodies do not protect the animal against the intracellular pathogen and in the final stages of infection suppression of the immune system and a state of anergy may occur (Waters et al., 1999). Diagnosis of MAP infected animals is frequently based on detection of antibodies in milk or serum, or by cultivation of bacteria from faeces, but these diagnostic methods are usually not applicable until years after infection at an advanced stage of disease (Nielsen and Toft, 2006). Contrary, CMI based diagnostics are applicable at an early stage of infection, prior to antibody formation and bacterial shedding in faeces. Hence, by using various diagnostic test strategies it is possible to detect infection with MAP at different stages of disease. The main limitation of available diagnostic tools is the lack of MAP specificity of included antigens resulting in poor specificity. 
59 The aim of the current review was to provide an overview of MAP antigen candidates that has been

60 used for diagnostic application to date. The emphasis will be on diagnostics measuring CMI,

61 although humoral based approaches and different types of antigen will also be discussed.

62 


\section{Literature review}

64 A review of MAP antigen candidates was carried out by searching the databases Web of Science and Medline through PubMed. The search terms were paratuberculosis; Johne's or Johnes combined with antigen and generated 1169 hits including duplicate records. The number of publications was reduced to 96 by exclusion of duplicate records and exclusion of studies, where the abstract indicated that the study did not test antigens for MAP diagnosis or did not characterize MAP antigens. From available publications the following information was extracted and tabulated: a) Antigen name, locus and gene name, if available; b) size in $\mathrm{kDa}$; $\mathrm{c}$ ) characteristic; d) whether the antigen candidate was purified from MAP or recombinant; e) immunogenicity of antigen candidate and type of assay, i.e. in vitro CMI, skin test, enzyme linked immunosorbent assay (ELISA); f) animal species and g) species specificity. These publications describe 115 different antigen candidates originating from MAP, antigen candidates from mycobacteria other than MAP used for MAP diagnosis, antigen candidates of different specificity and antigen discovery and characterisation by various approaches. 


\section{Immune-based test platforms for MAP diagnostics}

The true state of infection can often only be established through culture of multiple tissues.

However, bacterial growth is slow with test results being available only after months of incubation, and up to 100 tissues may be required to establish the infection status of an animal (Whitlock et al., 1996). Further, shedding of MAP at detectable levels in faeces is irregular (Nielsen and Toft, 2008). Therefore immune-based diagnostic tests are relevant alternatives to faecal culture and several tests measuring either specific CMI or antibodies have been developed.

\subsection{Host immune response to MAP}

MAP infected macrophages present antigens associated with major histocompatibility complex class I and II on the cell surface to $\mathrm{CD} 8+$ and $\mathrm{CD} 4^{+} \mathrm{T}$ cells. As a result $\mathrm{CD} 4^{+} \mathrm{T}$ helper type 1 cells $\left(\mathrm{T}_{\mathrm{H}} 1\right)$ are activated and produces a range of cytokines, including interferon- $\gamma(\mathrm{IFN}-\gamma)$. The $\mathrm{T}_{\mathrm{H}} 1$ cytokine signals through a network of receptors and starts a cascade of reactions characterising the CMI response (Coussens, 2001). As the infection progress, the CMI response wanes and an antibody-mediated $\mathrm{CD}^{+} \mathrm{T}$ helper type $2\left(\mathrm{~T}_{\mathrm{H}} 2\right)$ response becomes predominant. Antibody production provides little, if any, protection against MAP and the infection expands without the important $T_{H} 1$ cell subset, which is considered to be necessary for protective immunity (Toman et al., 2003). Therefore it appears that IFN- $\gamma$ producing $\mathrm{T}_{\mathrm{H}} 1$ cells recognizing peptide antigens are the major mediators of specific immunity early in the infection. Hence, specific T cell responses can be exploited for early detection of infection whereas assays of humoral responses may be relevant for detecting the later stages of MAP infection (Stabel, 2000). 


\subsection{CMI based diagnostics}

The intradermal skin test measures the delayed-type hyper-sensitivity response 72 hours after intradermal injection of purified protein derivative (PPD) (Kalis et al., 2003; Antognoli et al., 2007). PPDs are crude undefined extracts of mycobacterium antigens of different origin such as:

MAP (PPDj or Johnin), M. avium subsp. avium (MAA) (PPDa) or M. bovis (PPDb) (Gilot and

Cocito, 1993; Semret et al., 2006). For MAP diagnostics the situation is complicated by the lack of standardization of the PPD used. For many years the alleged reference strain 18 was used for preparation of antigens including PPDj, although it was later shown to be a laboratory adapted strain of M. avium that is not a representation of field strains of MAP isolated from cattle (Chiodini, 1993). Lack of standardized PPDs is of concern, because the genomic variability is considerably high in the organisms used for preparation of different PPDs (Semret et al., 2006). A standardized production of PPDs, including a detailed production protocol and the use of the same strains, would enable comparison of results from various laboratories.

Development of a positive skin test against PPDj is considered an indication of MAP infection.

However, the current skin test protocol based upon PPDs not only cross-reacts with environmental mycobacteria but also with currently used MAP and M. bovis vaccines (Köhler et al., 2001). Another drawback of the skin test is that each individual animal needs to be restrained twice within a period of $72 \mathrm{~h}$, first for the application of the test, and later for the reading of the results. As a consequence, the skin test has to some extent been replaced by an in vitro CMI assay measuring secreted IFN- $\gamma$ in response to an antigen (Wood et al., 1989).

The IFN- $\gamma$ assay requires only one intervention for blood collection. Whole blood samples are cultured with MAP antigens in a proliferation assay, and released IFN- $\gamma$ is measured in the supernatant by ELISA (Wood et al., 1989). Similar to the skin test, the current IFN- $\gamma$ MAP assay is based on PPD as antigen for stimulation and will therefore inherently have the same specificity 
problems. Furthermore, large scale use of the IFN- $\gamma$ assay for routine diagnostics is limited by the short timeframe of less than 24 hours allowed from blood sampling at the farm to stimulation with antigens in the laboratory (Jungersen et al., 2005). Finally, fluctuating IFN- $\gamma$ responses to PPDs in calves younger than 15 months puts another limitation of the usefulness of the IFN- $\gamma$ assay in its current form (Jungersen et al., 2002; Huda et al., 2003). We have previously investigated if the IFN$\gamma$ response to PPDj could be used as an early indicator of later antibody results in milk samples of cattle with different faecal culture status (Mikkelsen et al., 2009). Samples were collected during a period three years of 975 cows from 18 Danish MAP infected dairy herds. The study showed that a small but significant association exists between IFN- $\gamma$ test results obtained prior to first calving and milk antibody ELISA results at different ages after calving. In addition, we observed that only some of the IFN- $\gamma$ positive animals developed a positive antibody response against MAP, which may indicate that CMI responses can control or eradicate MAP in many animals.

\subsection{Serology based diagnostics}

Antibodies to MAP in serum can be detected by different methods such as: complement fixation (Morris and Stevens, 1977), agar gel immuno-diffusion (AGID) (Sherman et al., 1990) and ELISA (Reichel et al., 1999). AGID can reach a specificity of $100 \%$ but it is less sensitive than ELISA which is capable of detecting small amounts of antibodies and therefore show the highest sensitivity of the serological tests for MAP (Harris and Barletta, 2001). Specificity of ELISA tests has been improved by removing cross-reacting antibodies by absorbing sera with Mycobacterium phlei. Using this method, studies have reported ELISA specificity of $98.8 \%$ (Cox et al., 1991) and 99.7\% (Reichel et al., 1999). However, this absorption step compromises assay sensitivity. Sensitivity of serological tests is highest for animals with clinical symptoms as antibodies develop in the later stages of infection (Sweeney et al., 1995; Nielsen and Toft, 2008). Consequently, the main 
146 limitation of these antibody based assays is that they cannot be used for diagnosis of animals at an

147 early stage of infection. The major advantages of antibody based diagnostic assays are that it is

148 relatively easy to implement into a format that is useful for large scale screening, and can be used in

149 the field without any expensive equipment or highly trained personnel.

150 


\section{Mycobacterium avium subsp. paratuberculosis antigen candidates}

151

152

153

154

155

156

157

158

159

160

161

162

163

164

165

166

167

168

169

170

171

172

173

\subsection{The ideal diagnostic antigen}

To improve on CMI and serology based diagnostic assays it will be important to identify welldefined antigens contributing to high test sensitivity and specificity. In general, there is a lack of well-defined and standardized antigens for use in diagnostic assays even though a number of antigens have been described in the literature. The ideal characteristics of a new diagnostic MAP antigen are that it is antigenic, unique to MAP, recognized by MAP infected animals in the early subclinical stages of infection and that it remains detectable throughout the course of the disease. Thus far, no such antigen has been discovered for MAP infections. In practice, it is likely that a diagnostic test for MAP will require a cocktail of antigens due to the range of heterogeneous MHC molecules of out-bred animals (Kathaperumal et al., 2009) and due to differentiated antigen expression patterns of MAP bacteria (Radosevich et al., 2007). The same antigens will most likely not be useful for both CMI and serology assays.

\subsection{Antigen candidates for CMI diagnostics}

Specificity and sensitivity of CMI based assays are poor primarily because of the applied antigens. Most studies have been conducted using PPDs (Köhler et al., 2001). However, a number of studies have described novel well-defined MAP antigens for measuring CMI responses. Table 1 summarizes these antigen candidates based on publications from 1989 through 2009. The antigen candidates include secreted antigens, cell wall and membrane antigens, lipoproteins, heat shock proteins and hypothetical proteins. The earliest studies used native proteins purified from MAP: Avi-3 (Abe et al., 1989), A36-complex (Gilot et al., 1992), P30 (Burrells et al., 1995), alkyl hydroperoxid reductase $\mathrm{C}(\mathrm{AhpC})$ and alkyl hydroperoxid reductase $\mathrm{D}(\mathrm{AhpD})$ (Olsen et al., 2000), MPP14 (Olsen and Storset, 2001; Olsen et al., 2005) and MPB70 (Olsen et al., 2005). All of these 
174

175

176

177

178

179

180

181

182

183

184

185

186

187

188

189

190

191

192

193

194

195

196

197

antigens were described to recall CMI responses in in vitro assays but they all lacked MAP

specificity because of orthologues in other mycobacteria species. Two exceptions that were specific to MAP were antigens AphC and $\mathrm{AphD}$, as demonstrated by immunoblot reaction of monospecific rabbit antiserum against the two antigens with 9 MAP strain lysates but not with lysates from 20

other mycobacterial species, except $M$. gordonae that produced weak cross-reactive bands (Olsen et al., 2000). The diagnostic potential of AphC and AphD were evaluated in four goats experimentally infected with MAP. T cells from all four goats produced IFN- $\gamma$ to in vitro stimulation with either antigen, whereas a non-infected control animal did not respond. AhpC and AhpD are the most promising CMI antigens among the natively purified MAP antigens as they appear to be species specific with a high sensitivity.

In recent years recombinant antigen candidates have replaced purified antigen candidates in the development of diagnostic assays. The advantages of recombinant antigens over purified antigens are higher product yield, high homology of antigen preparation and faster production. Several recombinant antigen candidates have been evaluated for detection of CMI against MAP. In some studies the species specificity was validated by comparison of the recombinant antigen sequence with available sequences of other mycobacteria (Koets et al., 1999; Nagata et al., 2005; Rosseels et al., 2006). Only the $67 \mathrm{kDA}$ heat shock protein (HspX) was described to be species specific (Bannantine and Stabel, 2000). The remaining recombinant antigen candidates were either highly homologous to proteins in other mycobacteria species or the homology was not reported. Unfortunately, the HspX protein did not produce a CMI recall response when tested in cell culture from 10 infected cows (Bannantine and Stabel, 2000). Apart from HspX and heat shock protein 65 (Hsp65) (Koets et al., 1999; Nagabhushanam et al., 2001), which induced only a low CMI response in both mice (Nagabhushanam et al., 2001) and cattle (Koets et al., 1999) all the described recombinant antigen candidates in Table 1 were reported to produce a CMI response. 
198 To study recombinant heat shock protein 65 (Hsp65) and 70 (Hsp70) blood samples were collected

199 from 179 cows and distributed to groups of: cows naturally infected and vaccinated against MAP $200(n=30)$, naturally infected and not vaccinated $(n=79)$, clinical cases $(n=11)$ and non-infected animals 201 (n=59) all from dairy farms (Koets et al., 1999). Each group was further divided into groups of 202 faecal culture positive or negative cows. From blood, peripheral blood mononuclear cells were 203 purified to evaluate proliferative responses following stimulation with Hsp65 or Hsp70 compared to 204 PPDj. Proliferative responses to Hsp65 were generally low in all groups of cows whereas responses 205 to Hsp70 varied between groups. Highest proliferative responses was observed for the group of 206 faecal culture positive cows that were not vaccinated ( $88 \%$ positive), followed by faecal culture 207 negative cows that were vaccinated ( $93.3 \%$ positive), 54 faecal negative cows that were non208 vaccinated (74.1\% positive) and 11 clinical cases of faecal culture positive cows ( $72.2 \%$ positive). 209 In the control group, $30.5 \%$ produced a positive response to $\mathrm{Hsp} 70$ and $16.9 \%$ produced a positive 210 response to Hsp65, which indicate low specificity of both antigens.

211 Another large study including 54 young clinical healthy cattle was conducted by Olsen et al. (2005) 212 evaluating IFN- $\gamma$ responses to recombinant ESAT-6, PPDb, purified antigen MPP14 and purified antigen MPB70. The study investigated the role of unspecific IFN- $\gamma$ production by natural killer

214 (NK) cells in young animals and concluded that NK cells were responsible for a large proportion of 215 the IFN- $\gamma$ producing cells in peripheral blood mononuclear cells from uninfected calves. A third 216 study including a decent number of animals was the investigation of recombinant Ag85A, Ag85B 217 and Ag85C.This study included 18 healthy control cows, 16 low shedders and 4 medium shedders 218 and resulted in highest responses by cows from the group of medium shedders and lowest responses 219 in the healthy control cows (Shin et al., 2005). The remaining studies in Table 1 included a much 220 lower number of animals. Validation of immunogenicity of antigen candidates requires an 221 appropriate sample size otherwise the results cannot be applied to herd conditions with genetically 
heterogeneous animals demonstrating different stages of MAP infection. Further, some of the listed antigens in Table 1 remain to be validated in bovine species, as they have only been validated in other species such as mice, rabbits or guinea pigs.

\subsection{Types of characterized MAP antigen candidates}

The majority of characterised or described MAP antigen candidates were not tested as CMI diagnostic antigens but either tested for immunogenicity in humoral assays or no records of immune reactivity were published. These antigen candidates are grouped and listed as: secreted antigens (Table 2), cell wall and membrane antigens (Table 3), lipoprotein antigens (Table 4), heat shock antigens (Table 5) and hypothetical antigens (Table 6). Due to the limited number of animals included in most studies it is impossible to validate the influence of variance of host immune response between animals, changes in MAP protein expression profiles during infection progress and influence of disease stage.

\subsubsection{Secreted antigen candidates}

Secreted antigens (Table 2) are expected to be highly immunogenic or immunodominant due to their presence in the extracellular environment where they are more likely to encounter sensitized immune cells. This was confirmed in a study comparing secreted antigens from supernatants and antigens of intracellular origin (Cho and Collins, 2006). Serum from infected cattle was used for immunoblot analysis which showed that infected sera reacted more strongly to the secreted antigens compared to the antigens of intracellular origin. The majority of the antigen candidates were evaluated with relatively few positive and negative control sera. However, five recombinant antigens, MAP2411, ClpP (MAP2281c), Ppa (MAP0435c), MAP0593c and GreA (MAP1027c), were tested for immunogenicity with sera from 41 sheep with a known MAP infection and 41 non- 
infected control sheep (Gumber et al., 2009b). Two of these antigens, MAP0593c and ClpP reacted against $58.5 \%$ and $46.3 \%$ test positive sera and $12.1 \%$ and $4.9 \%$ of the negative control sera.

MAP2411 could not distinguish between MAP positive or negative serum samples. The specificity of these antigen candidates towards MAP was not reported and hence it is difficult to evaluate their usefulness. An earlier study tested recombinant antigens of Ag85A, Ag85B, Ag85C and SOD in an ELISA with sera from 60 MAP shedding cows and 22 non-shedding cows (Shin et al., 2004).

Antigens of the Ag85 complex and SOD showed high reactivity against sera from the MAP shedding cows and little reactivity against sera from the non-shedding cows. Conserved proteins such as antigens of the Ag85 complex (Dheenadhayalan et al., 2002) are found in all mycobacteria species. At the protein level the three Ag85 components of MAP share 99\% sequence identity with MAA (Rosseels et al., 2006). For vaccine design the use of conserved proteins may provide cross protection towards other infections as a positive side-effect. However, for diagnostic purposes this cross reactivity is undesirable as high specificity and sensitivity is essential. The specificity for MAP was not reported for a large part of the antigen candidates listed in Table 2.

\subsubsection{Cell wall and membrane antigens}

Antigen candidates originating from cell wall or membrane are listed in Table 3. Similar to secreted antigens, cell wall and membrane antigens are expected to be highly immunogenic due to their accessibility to components of the immune system. Several of the reported studies have characterised and tested a 34kDa membrane protein antigen candidate (p34) (Gilot et al., 1992; Ostrowski et al., 2003) or parts of the protein (Dekesel et al., 1993; Vannuffel et al., 1994; Malamo et al., 2006) that belongs to the major antigen complex A36. The p34 protein was reported to elicit a predominant humoral immune response (Dekesel et al., 1992) and to be MAP specific (Gilot et al., 1993). In general, the characterised antigen candidates were evaluated with sera of few animals. 
However, the polypeptide a362, which represent the carboxyl termini of p34, was evaluated by ELISA with sera from 208 MAP positive and 175 MAP negative cattle (Vannuffel et al., 1994). The peptide reacted with $40.4 \%$ of the positive samples and $5 \%$ of the negative samples and hence showed low sensitivity but high specificity. The majority of the listed antigen candidates were reported to cross react with other mycobacteria species (Table 3).

A comparative study of different mycobacteria species genomes showed that the major differences are in the gene products constituting the cell wall and in particular genes encoding the PE and PPE proteins (Marri et al., 2006), which are unique to mycobacteria. PE and PPE proteins are named after a proline-glutamic acid (PE) motif and a proline-proline-glutamic acid (PPE) motif found in conserved domains near the $\mathrm{N}$ termini in these proteins. Their function remains unknown but members of the family have been linked to virulence (Li et al., 2005b). A recent genomic comparison study concluded that several PPE proteins were unique to MAP compared to other members of the Mycobacterium avium complex (Mackenzie et al., 2009). These proteins may therefore be useful antigen candidates in MAP specific diagnostic assays. Two PPE proteins expressed on the MAP cell wall are listed in Table 3, MAP1506 and MAP3420c (Newton et al., 2009). Recombinant MAP3420c showed positive immunoblot reaction with sera from four MAP faecal culture positive cows and did not react with sera from four faecal culture negative cows. Three of the faecal culture positive cows were confirmed tissue culture positive, whereas one faecal culture negative cow were tested tissue culture positive. Sera from the eight cows were also tested by three commercial ELISAs, but only one, two and four of the cows tested positive in each ELISA. The two PPE proteins could be promising diagnostic antigen candidates, however orthologous genes were found in M. avium subsp. hominissuis and MAA genomes (Newton et al., 2009) and if they are expressed in these species it would jeopardize the specificity. 


\subsubsection{Lipoprotein antigens}

Lipids (Table 4) comprise a large part of the mycobacterial cell wall and, similar to cell wall antigens, many of these structures have demonstrated high seroreactivity as a consequence of their accessibility for antibodies and immune cells (Biet et al., 2008). In an early study lipoarabinomanan (LAM) was purified, analysed for chemical properties, and shown to react with serum from a MAP infected cow (Sugden et al., 1987). LAM is a highly immunodominant component of the MAP cell wall and has been widely used in serological assays for MAP diagnosis (Jark et al., 1997; Reichel et al., 1999). Antigen candidates L5P (Biet et al., 2008), Para-LP-01 (Eckstein et al., 2006) and lipopeptide PstA (Wu et al., 2009) were reported to be absent in MAA. The diagnostic value of these antigen candidates remains to be thoroughly validated with appropriate sample sizes.

\subsubsection{Heat shock protein antigens}

Hsp's (Table 5) are highly conserved molecules produced by both eukaryotic and prokaryotic cells.

Expression of Hsp's is upregulated during cellular stress, such as heat stress in response to infection and inflammation (Wu et al., 2007). In addition to their chaperone function, these proteins have demonstrated to play an important role in activation and modulation of dendritic cells (Langelaar et al., 2002). Due to their conserved nature Hsp's are likely to be immunogenic but are not ideal antigens for diagnostic purposes as cross reactivity with other bacteria are expected.

Five different Hsp antigen candidates are listed in Table 5: GroES, Hsp65K, Hsp70, MAP3840 and MAP3841. All five antigens were tested with relatively few sera, and as expected, none of them were reported to be MAP specific. One study focused on the interaction of Hsp70 and bovine antigen presenting cells investigating the use of recombinant Hsp70 as a tool to chaperone antigens into the cell to mediate a cytotoxic T-cell response initiated by presentation of antigens by MHC class I antigen presenting pathway (Langelaar et al., 2002). The results indicate that a Hsp70 
318 receptor is present on bovine dendritic cells and macrophages and that Hsp70 may be useful as an

319 adjuvant in vaccines, if not as the vaccine antigen itself (Koets et al., 2006).

320

\subsubsection{Hypothetical proteins}

322 Table 6 includes characterised hypothetical protein antigen candidates of unknown function or other

323 antigen candidates of MAP. The majority of the listed antigen candidates are recombinant proteins.

324 Several of these were reported from studies conducting large proteome analysis of MAP

325 (Bannantine et al., 2004; Bannantine et al., 2008; Hughes et al., 2008) and were validated with sera 326 from few animals. 
328

329

330

331

332

333

334

335

336

337

338

339

340

341

342

343

344

345

346

347

348

349

350

\section{Future studies}

In the pre-genomic era, the primary technique for discovery and characterization of novel MAP antigen candidates was immunoproteomics. Screening of expression libraries was employed in parallel but to a much lesser degree. With the completion of the MAP genome (Li et al., 2005a) proteomic approaches has opened up for more targeted strategies that will be exploited further in the future. Immunoproteomic approaches are based upon selection of antigen candidates by a combination of antigenicity and protein expression profiles (White et al., 1994). Proteins are resolved by two-dimensional (2D) gel-electrophoresis and interesting spots are identified by mass spectrometry followed by cloning, recombinant expression and ultimately testing for antigenicity with serology or CMI based assays (Bannantine and Paustian, 2006; Gumber and Whittington, 2009). Progress in proteomic techniques has resulted in high-resolution $2 \mathrm{D}$ electrophoresis proteomic maps comprising more than 1500 spots and combined with mass spectroscopy in the identification of several hundred expressed proteins (Leroy et al., 2007).

Comparison of the MAP genome against other mycobacteria genomes, including the highly homologous MAA genome, allowed the identification of coding sequences present only in MAP (Bannantine et al., 2002). Comparative studies revealed that less than 40 coding sequences are uniquely present in the MAP genome (Bannantine et al., 2002; Paustian et al., 2004). This relatively small number of unique coding sequences reflects the genetic similarity among members of the mycobacteria (Bannantine et al., 2003).

Isolation and mass spectrometric identification of $\mathrm{MHC}$ binding peptides is a new approach that will allow the selection of a limited number of highly relevant proteins based upon the MAP genome sequence being publicly available. As an alternative, the genome could be screened in silico in a non-biased way for epitopes that will be recognized by the bovine immune system 
351 (Lundegaard et al., 2007). This approach relies upon computer algorithms to identify T cell epitopes

352 that bind the MHC II most strongly and promiscuously. In order for a protein to be recognized

353 strongly in a diagnostic test over the entire course of infection it has to be constitutively and

354 strongly expressed. Two recent studies demonstrated that protein expression of MAP differ from

355 control conditions during starvation, hypoxia (Gumber et al., 2009a) and heat stress (Gumber and

356 Whittington, 2009) in MAP strains originating from cattle and sheep. These results suggest that

357 MAP expresses a diverse range of antigens throughout the course of infection during which the

358 environmental conditions for the MAP bacteria change.

359 Regardless of which strategy we choose to follow there is currently no reliable way to predict

360 diagnostic antigens and we are left with the task of screening each selected antigen for its potential,

361 but in contrast to screening of the entire proteome it will be a doable task. 
363 A number of MAP antigen candidates of different characteristic and species specificity have been

364 identified and tested for immunogenicity to evaluate their diagnostic potential. Few of these

365 antigens have been tested for CMI reactions that allow for early detection of MAP infected animals.

366 Until now, no obvious antigen candidates for use in a CMI based diagnostic assay have been

367 identified. However, with several mycobacteria genome sequences available along with new tools

368 for in silico analysis and genomic techniques, specific and immunogenic antigens for

369 paratuberculosis diagnosis should be expected soon. It is recommended that appropriate sample size

370 is included for validation of future antigen candidates for diagnostic purposes. In addition, the use

371 of a selected antigen cocktail for diagnostic application should be considered, to ensure that all

372 infected animals are detected independent of disease status and MHC make-up. 


\section{References}

375

376

Abe, C., Saito, H., Tomioka, H., Fukasawa, Y., 1989. Production of a monoclonal antibody specific for Mycobacterium avium and immunological activity of the affinity-purified antigen. Infect. Immun. 57, 1095-1099.

Antognoli, M.C., Hirst, H.L., Garry, F.B., Salman, M.D., 2007. Immune response to and faecal shedding of Mycobacterium avium subsp. paratuberculosis in young dairy calves, and the association between test results in the calves and the infection status of their dams. Zoonoses Public Health 54, 152-159.

Bannantine, J.P., Baechler, E., Zhang, Q., Li, L.L., Kapur, V., 2002. Genome scale comparison of Mycobacterium avium subsp. paratuberculosis with Mycobacterium avium subsp. avium reveals potential diagnostic sequences. J. Clin. Microbiol. 40, 1303-1310.

Bannantine, J.P., Hansen, J.K., Paustian, M.L., Amonsin, A., Li, L.L., Stabel, J.R., Kapur, V., 2004. Expression and immunogenicity of proteins encoded by sequences specific to Mycobacterium avium subsp. paratuberculosis. J. Clin. Microbiol. 42, 106-114.

Bannantine, J.P., Paustian, M.L., 2006. Identification of diagnostic proteins in Mycobacterium avium subspecies paratuberculosis by a whole genome analysis approach. Methods in Molecular Biology. pp. 185-196.

Bannantine, J.P., Stabel, J.R., 2000. HspX is present within Mycobacterium paratuberculosisinfected macrophages and is recognized by sera from some infected cattle. Vet. Microbiol. 76, 343-358.

Bannantine, J.P., Waters, W.R., Stabel, J.R., Palmer, M.V., Li, L.L., Kapur, V., Paustian, M.L., 2008. Development and use of a partial Mycobacterium avium subspecies paratuberculosis protein array. Proteomics 8, 463-474. 
Bannantine, J.P., Zhang, Q., Li, L.L., Kapur, V., 2003. Genomic homogeneity between Mycobacterium avium subsp. avium and Mycobacterium avium subsp. paratuberculosis belies their divergent growth rates. BMC Microbiol. 3.

Beard, P.M., Daniels, M.J., Henderson, D., Pirie, A., Rudge, K., Buxton, D., Rhind, S., Greig, A., Hutchings, M.R., McKendrick, I., Stevenson, K., Sharp, J.M., 2001. Paratuberculosis infection of nonruminant wildlife in Scotland. J. Clin. Microbiol. 39, 1517-1521.

Biet, F., Bay, S., Thibault, V.C., Euphrasie, D., Grayon, M., Ganneau, C., Lanotte, P., Daffq, M., Gokhale, R., Etienne, G., Reyrat, J.M., 2008. Lipopentapeptide induces a strong host humoral response and distinguishes Mycobacterium avium subsp. paratuberculosis from M. avium subsp. avium. Vaccine 26, 257-268.

Burrells, C., Inglis, N.F., Davies, R.C., Sharp, J.M., 1995. Detection of specific T cell reactivity in sheep infected with Mycobacterium avium subspecies silvaticum and paratuberculosis using two defined mycobacterial antigens. Vet. Immunol. Immunopathol. 45, 311-320.

Chiodini, R.J., 1993. Abolish Mycobacterium paratuberculosis strain 18. J. Clin. Microbiol. 31, 1956-1958.

Chiodini, R.J., 1996. Immunology: Resistance to paratuberculosis. Vet. Clin. North. Am. Food. Anim. Pract. 12, 313-343.

Chiodini, R.J., Vankruiningen, H.J., Merkal, R.S., 1984. Ruminant paratuberculosis (Johne's Disease) - the current status and future prospects. Cornell Vet. 74, 218-262.

Cho, D., Collins, M.T., 2006. Comparison of the proteosomes and antigenicities of secreted and cellular proteins produced by Mycobacterium paratuberculosis. Clin. Vaccine Immunol. 13, 1155-1161.

Coussens, P.M., 2001. Mycobacterium paratuberculosis and the bovine immune system. Anim. Hlth. Res. Rev. 2, 141-161. 
Cox, J.C., Drane, D.P., Jones, S.L., Ridge, S., Milner, A.R., 1991. Development and evaluation of a rapid absorbed enzyme immunoassay test for the diagnosis of Johne's disease in cattle. Aust. Vet. J. 68, 157-160.

Dekesel, M., Gilot, P., Coene, M., Cocito, C., 1992. Composition and immunological properties of the protein fraction of A36, a major antigen complex of Mycobacterium paratuberculosis. Scand. J. Immunol. 36, 201-212.

Dekesel, M., Gilot, P., Misonne, M.C., Coene, M., Cocito, C., 1993. Cloning and expression of portions of the 34-Kilodalton-protein gene of Mycobacterium paratuberculosis: Its application to serological analysis of Johne's disease. J. Clin. Microbiol. 31, 947-954.

Dheenadhayalan, V., Shin, K.S., Chang, C.F., Chang, C.D., Wang, S.J., McDonough, S., McDonough, P., Stehman, S., Shin, S., Torres, A., Chang, Y.F., 2002. Cloning and characterization of the genes coding for antigen 85A, 85B and 85C of Mycobacterium avium subsp. paratuberculosis. DNA Seq. 13, 287-294.

Eckstein, T.M., Chandrasekaran, S., Mahapatra, S., Mcneil, M.R., Chatterjee, D., Rithner, C.D., Ryan, P.W., Belisle, J.T., Inamine, J.M., 2006. A major cell wall lipopeptide of Mycobacterium avium subspecies paratuberculosis. J. Biol. Chem. 281, 5209-5215.

Gilot, P., Cocito, C., 1993. Comparative analysis of three sensitins used in cutaneous testing for tuberculosis and paratuberculosis in cattle. FEMS Microbiol. Lett. 110, 307-311.

Gilot, P., Dekesel, M., Coene, M., Cocito, C., 1992. Induction of cellular immune-reactions by A36, an antigen complex of Mycobacterium paratuberculosis: comparison of A36 and Johnin components. Scand. J. Immunol. 36, 811-821.

Gilot, P., Dekesel, M., Machtelinckx, L., Coene, M., Cocito, C., 1993. Isolation and sequencing of the gene coding for an antigenic 34-Kilodalton protein of Mycobacterium paratuberculosis. J. Bacteriol. 175, 4930-4935. 
445 Gumber, S., Taylor, D.L., Marsh, I.B., Whittington, R.J., 2009a. Growth pattern and partial $446 \quad$ proteome of Mycobacterium avium subsp. paratuberculosis during the stress response to hypoxia and nutrient starvation. Vet. Microbiol. 133, 344-357.

Gumber, S., Taylor, D.L., Whittington, R.J., 2009b. Evaluation of the immunogenicity of recombinant stress-associated proteins during Mycobacterium avium subsp. paratuberculosis infection: Implications for pathogenesis and diagnosis. Vet. Microbiol. 137, 290-296.

Gumber, S., Whittington, R.J., 2009. Analysis of the growth pattern, survival and proteome of Mycobacterium avium subsp. paratuberculosis following exposure to heat. Vet. Microbiol. 136, 82-90.

Harris, N.B., Barletta, R.G., 2001. Mycobacterium avium subsp. paratuberculosis in veterinary medicine. Clin. Microbiol. Rev. 14, 489-512.

Huda, A., Lind, P., Christoffersen, A.B., Jungersen, G., 2003. Analysis of repeated tests for interferon-gamma (IFN-g) response and faecal excretion for diagnosis of subclinical paratuberculosis in Danish cattle. Vet. Immunol. Immunopathol. 94, 95-103.

Hughes, V., Bannantine, J.P., Denham, S., Smith, S., Garcia-Sanchez, A., Sales, J., Paustian, M.L., Mclean, K., Stevenson, K., 2008. Immunogenicity of proteome-determined Mycobacterium avium subsp. paratuberculosis-specific proteins in sheep with paratuberculosis. Clin. Vaccine Immunol. 15, 1824-1833.

Jark, U., Ringena, I., Franz, B., Gerlach, G.F., Beyerbach, M., Franz, B., 1997. Development of an ELISA technique for serodiagnosis of bovine paratuberculosis. Vet. Microbiol. 57, 189-198.

Jungersen G., Grell S.N., Clemensen A., Roust T., Huda A., Howard C.J., 2005. Interleukin-12 potentiation of the interferon-gamma test rescues day-old blood samples for diagnosis of paratuberculosis PPD specific cellular mediated immune response. In :Manning E.J.B., 
Nielsen S.S. (editors), Proceedings of the 8th International Colloquium on Paratuberculosis, Copenhagen, Denmark, August 14-17 2005, 501-506.

Jungersen, G., Huda, A., Hansen, J.J., Lind, P., 2002. Interpretation of the gamma interferon test for diagnosis of subclinical paratuberculosis in cattle. Clin. Diagn. Lab. Immunol. 9, 453-460.

Kalis, C.H.J., Collins, M.T., Hesselink, J.W., Barkema, H.W., 2003. Specificity of two tests for the early diagnosis of bovine paratuberculosis based on cell-mediated immunity: the Johnin skin test and the gamma interferon assay. Vet. Microbiol. 97, 73-86.

Kathaperumal, K., Kumanan, V., McDonough, S., Chen, L.H., Park, S.U., Moreira, M.A.S., Akey, B., Huntley, J., Chang, C.F., Chang, Y.F., 2009. Evaluation of immune responses and protective efficacy in a goat model following immunization with a coctail of recombinant antigens and a polyprotein of Mycobacterium avium subsp. paratuberculosis. Vaccine 27, 123-135.

Koets, A., Hoek, A., Langelaar, M., Overdijk, M., Santema, W., Franken, P., van Eden, W., Rutten, V., 2006. Mycobacterial $70 \mathrm{kD}$ heat-shock protein is an effective subunit vaccine against bovine paratuberculosis. Vaccine $24,2550-2559$.

Koets, A.P., Rutten, V.P.M.G., Hoek, A., Bakker, D., van Zijderveld, F., Muller, K.E., van Eden, W., 1999. Heat-shock protein-specific T-cell responses in various stages of bovine paratuberculosis. Vet. Immunol. Immunopathol. 70, 105-115.

Köhler, H., Gyra, H., Zimmer, K., Drager, K.G., Burkert, B., Lemser, B., Hausleithner, D., Cussler, K., Klawonn, W., Hess, R.G., 2001. Immune reactions in cattle after immunization with a Mycobacterium paratuberculosis vaccine and implications for the diagnosis of $M$. paratuberculosis and M. bovis infections. J. Vet. Med. B 48, 185-195. 
Langelaar, M., Koets, A., Muller, K., van Eden, W., Noordhuizen, J., Howard, C., Hope, J., Rutten, V., 2002. Mycobacterium paratuberculosis heat shock protein 70 as a tool in control of paratuberculosis. Vet. Immunol. Immunopathol. 87, 239-244.

Leroy, B., Roupie, V., Noel-Georis, I., Rosseels, V., Walravens, K., Govaerts, M., Huygen, K., Wattiez, R., 2007. Antigen discovery: A postgenomic approach to paratuberculosis diagnosis. Proteomics 7, 1164-1176.

Li, L.L., Bannantine, J.P., Zhang, Q., Amonsin, A., May, B.J., Alt, D., Banerji, N., Kanjilal, S., Kapur, V., 2005a. The complete genome sequence of Mycobacterium avium subspecies paratuberculosis. Proc. Natl. Acad. Sci. U. S. A. 102, 12344-12349.

Li, Y.J., Miltner, E., Wu, M., Petrofsky, M., Bermudez, L.E., 2005b. A Mycobacterium avium PPE gene is associated with the ability of the bacterium to grow in macrophages and virulence in mice. Cellular Microbiology 7, 539-548.

Lundegaard, C., Lund, O., Kesmir, C., Brunak, S., Nielsen, M., 2007. Modeling the adaptive immune system: predictions and simulations. Bioinformatics 23, 3265-3275.

Mackenzie, N., Alexander, D.C., Turenne, C.Y., Behr, M.A., De Buck, J.M., 2009. Genomic comparison of PE and PPE genes in the Mycobacterium avium Complex. J. Clin. Microbiol. 47, 1002-1011.

Malamo, M., Sakoda, Y., Ozaki, H., Kida, H., 2006. Development of ELISA to detect antibodies specific to Mycobacterium avium subsp. paratuberculosis with truncated $34 \mathrm{kDa}$ proteins. Jpn. J. Vet. Res. 54, 99-107.

Marri, P.R., Bannantine, J.P., Golding, G.P., 2006. Comparative genomics of metabolic pathways in Mycobacterium species: gene duplication, gene decay and lateral gene transfer. FEMS Microbiol. Rev. 30, 906-925. 
Mikkelsen, H., Jungersen, G., Nielsen, S.S., 2009. Association between milk antibody and interferon-gamma responses in cattle from Mycobacterium avium subsp. paratuberculosis infected herds. Vet. Immunol. Immunopathol. 127, 235-241.

Morris, J.A., Stevens, A.E., 1977. Improved antigen for paratuberculosis complement fixation test. J. Biol. Stand. 5, 315-319.

Nagabhushanam, V., Praszkier, J., Cheers, C., 2001. Molecular and immunological characterization of Mycobacterium avium $65 \mathrm{kDa}$ heat shock protein (Hsp65). Immunol. Cell Biol. 79, 454461.

Nagata, R., Muneta, Y., Yoshihara, K., Yokomizo, Y., Mori, Y., 2005. Expression cloning of gamma interferon-inducing antigens of Mycobacterium avium subsp. paratuberculosis. Infect. Immun. 73, 3778-3782.

Newton, V., McKenna, S.L., De Buck, J., 2009. Presence of PPE proteins in Mycobacterium avium subsp. paratuberculosis isolates and their immunogenicity in cattle. Vet. Microbiol. 135, 394400.

Nielsen, S.S., Toft, N., 2006. Age-specific characteristics of ELISA and fecal culture for purposespecific testing for paratuberculosis. J. Dairy Sci. 89, 569-579.

Nielsen, S.S., Toft, N., 2008. Ante mortem diagnosis of paratuberculosis: A review of accuracies of ELISA, interferon-gamma assay and faecal culture techniques. Vet. Microbiol. 129, 217-235.

Olsen, I., Boysen, P., Kulberg, S., Hope, J.C., Jungersen, G., Storset, A.K., 2005. Bovine NK cells can produce gamma interferon in response to the secreted mycobacterial proteins ESAT- 6 and MPP14 but not in response to MPB70. Infect. Immun. 73, 5628-5635.

Olsen, I., Reitan, L.J., Holstad, G., Wiker, H.G., 2000. Alkyl hydroperoxide reductases C and D are major antigens constitutively expressed by Mycobacterium avium subsp. paratuberculosis. Infect. Immun. 68, 801-808. 
Olsen, I., Storset, A.K., 2001. Innate IFN-gamma production in cattle in response to MPP14, a secreted protein from Mycobacterium avium subsp. paratuberculosis . Scand. J. Immunol. 54, 306-313.

Ostrowski, M., Mundo, S.L., Harris, N.B., Barletta, R.G., Lopez, O.J., 2003. B-cell epitopes in the immunodominant p34 antigen of Mycobacterium avium ssp. paratuberculosis recognized by antibodies from infected cattle. Scand. J. Immunol. 58, 511-521.

Ott, S.L., Wells, S.J., Wagner, B.A., 1999. Herd-level economic losses associated with Johne's disease on US dairy operations. Prev. Vet. Med. 40, 179-192.

Paustian, M.L., Amonsin, A., Kapur, V., Bannantine, J.P., 2004. Characterization of novel coding sequences specific to Mycobacterium avium subsp. paratuberculosis: Implications for diagnosis of Johne's disease. J. Clin. Microbiol. 42, 2675-2681.

Radosevich, T.J., Reinhardt, T.A., Lippolis, J.D., Bannantine, J.P., Stabel, J.R., 2007. Proteome and differential expression analysis of membrane and cytosolic proteins from Mycobacterium avium subsp. paratuberculosis strains K-10 and 187. J. Bacteriol. 189, 1109-1117.

Reichel, M.P., Kittelberger, R., Penrose, M.E., Meynell, R.M., Cousins, D., Ellis, T., Mutharia, L.M., Sugden, E.A., Johns, A.H., de Lisle, G.W., 1999. Comparison of serological tests and faecal culture for the detection of Mycobacterium avium subsp. paratuberculosis infection in cattle and analysis of the antigens involved. Vet. Microbiol. 66, 135-150.

Rosseels, V., Marche, S., Roupie, V., Govaerts, M., Godfroid, J., Walravens, K., Huygen, K., 2006. Members of the 30- to 32-kilodalton mycolyl transferase family (Ag85) from culture filtrate of Mycobactelium avium subsp. paratuberculosis are immunodominant Th1-type antigens recognized early upon infection in mice and cattle. Infect. Immun. 74, 202-212. 
Semret, M., Bakker, D., Smart, N., Olsen, I., Haslov, K., Behr, M.A., 2006. Genetic analysis of Mycobacterium avium complex strains used for producing purified protein derivatives. Clin. Vaccine Immunol. 13, 991-996.

Sherman, D.M., Gay, J.M., Bouley, D.S., Nelson, G.H., 1990. Comparison of the complementfixation and agar-gel immunodiffusion tests for diagnosis of subclinical bovine paratuberculosis. Am. J. Vet. Res. 51, 461-465.

Shin, S.J., Chang, C.F., Chang, C.D., McDonough, S.P., Thompson, B., Yoo, H.S., Chang, Y.F., 2005. In vitro cellular immune responses to recombinant antigens of Mycobacterium avium subsp. paratuberculosis. Infect. Immun. 73, 5074-5085.

Shin, S.J., Yoo, H.S., McDonough, S.P., Chang, Y.F., 2004. Comparative antibody response of five recombinant antigens in related to bacterial shedding levels and development of serological diagnosis based on $35 \mathrm{kDa}$ antigen for Mycobacterium avium subsp. paratuberculosis. J. Vet. Sc. 5, 111-117.

Stabel, J.R., 2000. Transitions in immune responses to Mycobacterium paratuberculosis. Vet. Microbiol. 77, 465-473.

Sugden, E.A., Samagh, B.S., Bundle, D.R., Duncan, J.R., 1987. Lipoarabinomannan and lipid-free arabinomannan antigens of Mycobacterium paratuberculosis. Infect. Immun. 55, 762-770.

Sweeney, R.W., 1996. Transmission of paratuberculosis. Vet. Clin. North. Am. Food. Anim. Pract. $12,305-312$

Sweeney, R.W., Whitlock, R.H., Buckley, C.L., Spencer, P.A., 1995. Evaluation of a commercial enzyme-linked immunosorbent asay for the diagnosis of paratuberculosis in dairy cattle. J. Vet. Diagn. Invest. 7, 488-493.

Toman, M., Faldyna, M., Pavlik, I., 2003. Immunological characteristics of cattle with Mycobacterium avium subsp. paratuberculosis infection. Vet. Med. 48, 147-154. 
Turenne, C.Y., Wallace, R., Jr., Behr, M.A., 2007. Mycobacterium avium in the postgenomic era. Clin. Microbiol. Rev. 20, 205-229.

Vannuffel, P., Gilot, P., Limbourg, B., Naerhuyzen, B., Dieterich, C., Coene, M., Machtelinckx, L., Cocito, C., 1994. Development of species specific enzyme-linked immunosorbent assay for diagnosis of Johne's Disease in cattle. J. Clin. Microbiol. 32, 1211-1216.

Waters, W.R., Stabel, J.R., Sacco, R.E., Harp, J.A., Pesch, B.A., Wannemuehler, M.J., 1999. Antigen-specific B-cell unresponsiveness induced by chronic Mycobacterium avium subsp. paratuberculosis infection of cattle. Infect. Immun. 67, 1593-1598.

White, W.B., Whipple, D.L., Stabel, J.R., Bolin, C.A., 1994. Comparison of cellular and extracellular proteins expressed by various isolates of Mycobacterium paratuberculosis and other mycobacterial species. Am. J. Vet. Res. 55, 1399-1405.

Whitlock R.H., Rosenberger A.E., Sweeney R., Spencer P.A., 1996. Distribution of M. paratuberculosis in tissues of cattle from herds infected with Johne's disease. In :Chiodini R.J., Hines M.E., Collins M.T. (editors), Proceedings of the Fifth International Colloquium on Paratuberculosis, Sept.29-Oct.4, 1996, Madison, Wisconsin, USA, 168-174.

Wood P.R., Kopsidas K., Milner A.R., Hill J., Gill I., Webb R. et al., 1989. The development of an in vitro cellular assay for Johne's disease in cattle. In :Milner A.R., Wood P.R. (editors), Johne's Disease: current trends in research, diagnosis and management, 164-167.

Wu, C.W., Schmoller, S.K., Shin, S.J., Talaat, A.M., 2007. Defining the stressome of Mycobacterium avium subsp. paratuberculosis in vitro and in naturally infected cows. J. Bacteriol. 189, 7877-7886.

Wu, C.w., Schmoller, S.K., Bannantine, J.P., Eckstein, T.M., Inamine, J.M., Livesey, M., Albrecht, R., Talaat, A.M., 2009. A novel cell wall lipopeptide is important for biofilm formation and 
607 $222-230$.

608 
Table 1. Antigen candidates tested for cell mediated immunity against Mycobacterium avium subsp. paratuberculosis.

\begin{tabular}{|c|c|c|c|c|c|c|c|c|}
\hline Antigen & Locus & Gene & $\begin{array}{l}\text { Size } \\
(\mathbf{k D a})\end{array}$ & Characteristic & Antigen & Test assay & MAP specific & Reference \\
\hline \multicolumn{9}{|l|}{ Secreted } \\
\hline MPP14 & - & - & 14 & Protein from MAA complex & Purified & $\begin{array}{l}\text { IFN- } \gamma \text { test, resp. of } 14 \text { calves during two } \\
\text { months. pos: } 5 / 7 \text { pos and } 0 / 7 \text { neg }\end{array}$ & Specific for MAA & Olsen et al., 2005 \\
\hline MPP14 & - & - & 14 & Protein of MAIS complex & Purified & $\begin{array}{l}\text { IFN- } \gamma \text { test, pos: } 6 / 8 \text { MAP inf, } 1 / 7 \text { control } 23 \\
\text { weeks p.i. }\end{array}$ & No & Olsen and Storset, 2001 \\
\hline МРT-TP & - & - & 16.7 & Hypothetical thiol peroxidase & Recombinant & $\begin{array}{l}\text { IFN- } \gamma \text { response of pooled mice spleen cells from } \\
24-60 \text { mice }\end{array}$ & Not reported & Mullerad et al., 2003 \\
\hline SOD & - & - & 28 & Superoxide dismutase & Recombinant & $\begin{array}{l}\text { IFN- } \gamma \text { signf. higher of } 20 \mathrm{FC} \text { pos vs. } 18 \mathrm{FC} \text { neg } \\
\text { cows }\end{array}$ & $\begin{array}{l}\text { 81-93\% homologous to } \mathrm{M} . \mathrm{TB} \\
\text { and } M . \text { leprae, M. habana }\end{array}$ & Mullerad et al., 2002a \\
\hline P30 & - & - & 30 & Protein & Purified & IFN- $\gamma$ test, pos: $2 / 2$ MAP inf., $0 / 2$ uninf. sheep & $\begin{array}{l}\text { Homologous to other } \\
\text { mycobacteria }\end{array}$ & Burrells et al., 1995 \\
\hline $\operatorname{Ag} 85 \mathrm{~A}$ & MAP0216 & $f b p A$ & $30-32$ & Protein, T-cell epitope & Recombinant & $\begin{array}{l}\text { IFN- } \gamma \text { test, pos: } 5 \text { inf. mice (Ag85A) and } 5 \text { inf. } \\
\text { calves (Ag85 complex) }\end{array}$ & $\begin{array}{l}\text { Iidentical sequence in } M \text {. } \\
\text { bovis }\end{array}$ & Rosseels et al., 2006 \\
\hline $\operatorname{Ag} 85 \mathrm{~A}$ & MAP0216 & $f b p A$ & $30-32$ & Protein, T-cell epitope & Recombinant & $\begin{array}{l}\text { IFN- } \gamma \text { signf. higher of } 20 \mathrm{FC} \text { pos vs. } 18 \mathrm{FC} \text { neg } \\
\text { cows }\end{array}$ & Identical sequence in $M$. bovis & Shin et al., 2005 \\
\hline $\mathrm{Ag} 85 \mathrm{~B}$ & MAP1609c & $f b p B$ & $30-32$ & Protein, T-cell epitope & Recombinant & $\begin{array}{l}\text { IFN- } \gamma \text { test, pos: } 5 \text { inf. mice (Ag85B) and } 5 \text { inf. } \\
\text { calves (Ag85 complex) }\end{array}$ & Identical sequence in $M$. bovis & Rosseels et al., 2006 \\
\hline Ag85B & MAP1609c & $f b p B$ & $30-32$ & Protein, T-cell epitope & Recombinant & $\begin{array}{l}\text { IFN- } \gamma \text { signf. higher of } 20 \mathrm{FC} \text { pos vs. } 18 \mathrm{FC} \text { neg } \\
\text { cows }\end{array}$ & Identical sequence in $M$. bovis & Shin et al., 2005 \\
\hline $\mathrm{Ag} 85 \mathrm{C}$ & MAP3531c & $f b p C 2$ & $30-32$ & Protein, T-cell epitope & Recombinant & $\begin{array}{l}\text { IFN- } \gamma \text { test, pos: } 5 \text { inf. mice (Ag85C, low resp.) } \\
\text { and } 5 \text { inf. calves (Ag85 complex) }\end{array}$ & Identical sequence in $M$. bovis & Rosseels et al., 2006 \\
\hline $\mathrm{Ag} 85 \mathrm{C}$ & MAP3531c & $f b p C 2$ & $30-32$ & Protein, T-cell epitope & Recombinant & $\begin{array}{l}\text { IFN- } \gamma \text { signf. higher of } 20 \mathrm{FC} \text { pos vs. } 18 \mathrm{FC} \text { neg } \\
\text { cows }\end{array}$ & Identical sequence in $M$. bovis & Shin et al., 2005 \\
\hline ESAT-6 & - & - & - & $\begin{array}{l}\text { Early secretory antigenic target } 6 \text { of M.TB } \\
\text { complex }\end{array}$ & Recombinant & $\begin{array}{l}\text { IFN- } \gamma \text { test, resp. of } 14 \text { calves during two } \\
\text { months, pos: } 7 / 7 \text { pos and } 1 / 7 \text { neg }\end{array}$ & No & Olsen et al., 2005 \\
\hline MPB70 & - & - & - & Protein from M.TB complex & Purified & $\begin{array}{l}\text { IFN- } \gamma \text { test, resp. of } 14 \text { calves during two } \\
\text { months, pos: } 0 / 7 \text { pos and } 0 / 7 \text { neg }\end{array}$ & No & Olsen et al., 2005 \\
\hline SOD & - & - & - & Superoxide dismutase & Recombinant & $\begin{array}{l}\text { IFN- } \gamma \text { signf. higher of SOD imm. mice vs. } \\
\text { control mice. Pooled samples of } 24-60 \text { mice }\end{array}$ & No & Shin et al., 2005 \\
\hline \multicolumn{9}{|c|}{ Cell wall and membrane } \\
\hline Map39 & Map3184 & - & 39 & $\begin{array}{l}\text { Possible T-cell Ag, homologous to PPE } \\
\text { protein family. Hypothetical protein }\end{array}$ & Recombinant & IFN- $\gamma$ test, pos*: $5 / 5$ pos and $0 / 5$ neg & Homologous to MAA & Nagata et al., 2005 \\
\hline Map41 & Map1518 & - & 41 & $\begin{array}{l}\text { Possible T-cell Ag, homologous to PPE } \\
\text { protein family. Hypothetical protein }\end{array}$ & Recombinant & IFN- $\gamma$ test, pos*: $5 / 5$ pos and $0 / 5$ neg & Homologous to MAA & Nagata et al., 2005 \\
\hline $\begin{array}{l}\text { A36- } \\
\text { complex }\end{array}$ & - & - & 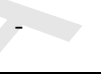 & TMA family, part of PPD & Purified & Skin test: reaction to A36 by sensitized rabbits & $94 \%$ homology to MAA & Gilot et al., 1992 \\
\hline \multicolumn{9}{|l|}{ Lipoproteins } \\
\hline MAP0261c & MAP0261c & - & 19 & $\begin{array}{l}\text { Homologue protein of M. TB is } \\
\text { immunodominant in mice and humans }\end{array}$ & Recombinant & $\begin{array}{l}\text { IFN- } \gamma \text { test: low resp, but signf. difference } \\
\text { between } 21 \text { naturally inf and } 9 \text { neg control cows }\end{array}$ & $\begin{array}{l}\text { Homologues in } M . \text { bovis, } \\
\text { MAA and } M \text {. intracellulare }\end{array}$ & Huntley et al., 2005 \\
\hline MAP1138c & MAP1138c & $\operatorname{lpr} G$ & 22 & Exported lipoprotein (LppX/LprAFG family) & $\begin{array}{l}\text { Purified/ } \\
\text { recombinant }\end{array}$ & $\begin{array}{l}\text { Proliferation assay, no signf. difference between } \\
\text { MAP FC pos }(\mathrm{n}=12) \text { and FC neg }(\mathrm{n}=14) \text { cows. } \\
\text { Serum antibody levels: signf. difference } \\
\text { between groups }\end{array}$ & $67 \%$ homology with M. bovis & Santema et al., 2009 \\
\hline $\mathrm{P} 22$ & MAP1138c & $\operatorname{lpr} G$ & 22 & Exported lipoprotein (LppX/LprAFG family) & Recombinant & $\begin{array}{l}\text { IFN- } \gamma \text { test, pos: } 8 / 9 \text { MAP vaccinated and } 0 / 5 \\
\text { control sheep }\end{array}$ & $\begin{array}{l}75 \% \text { homology with M. leprae } \\
\text { and M.TB }\end{array}$ & Dupont et al., 2005 \\
\hline P22 & MAP1138c & $\operatorname{lprG}$ & 22 & Exported lipoprotein (LppX/LprAFG family) & Recombinant & IFN- $\gamma$ test, pos: $3 / 5$ and $2 / 5$ P22-imm sheep and & 75\% homology with M. leprae & Rigden et al., 2006 \\
\hline
\end{tabular}




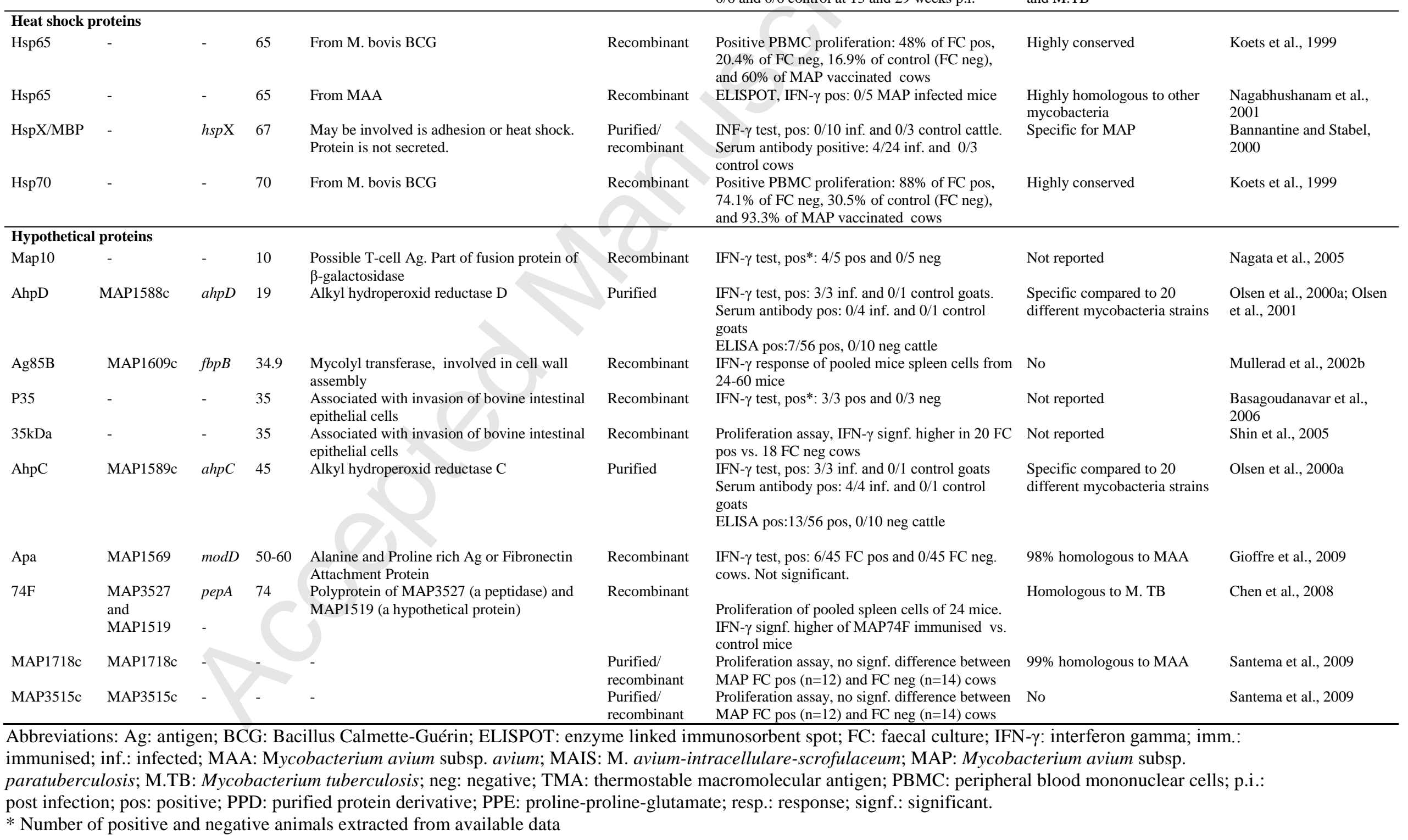


Table 2. Characterized secreted antigen candidates of Mycobacterium avium subsp. paratuberculosis

\begin{tabular}{|c|c|c|c|c|c|c|c|c|}
\hline Antigen & Locus & Gene & $\begin{array}{l}\text { Size } \\
\text { (kDa) }\end{array}$ & Characteristic & Antigen & Test assay & MAP specific & Reference \\
\hline MAP2609 & MAP2609 & - & 9 & Conserved hypothetical protein & Recombinant & Immunoblot pos: 11/11 pos & $\begin{array}{l}\text { Homologous to } M . T B \text { and } M \text {. } \\
\text { bovis }\end{array}$ & Willemsen et al., 2006 \\
\hline MAP0593c & MAP0593c & - & 14.7 & $\begin{array}{l}\text { Hypothetical protein. Degradation of proteins, } \\
\text { peptides, and glycopeptides }\end{array}$ & Recombinant & ELISA pos: $24 / 41$ pos and $5 / 41 \mathrm{neg}$ & Not reported & Gumber et al., 2009 \\
\hline $14 \mathrm{kDa}$ & - & & 14 & Putative signal peptide & Purified & $\begin{array}{l}\text { Immunoblot pos } \\
\text { ELISA pos: } 13 / 30 \text { pos; } 1 / 10 \mathrm{neg}\end{array}$ & $\begin{array}{l}\text { Homologous in all species of } \\
\text { MAC }\end{array}$ & $\begin{array}{l}\text { Olsen et al., 2000b; Olsen et al., } \\
2001\end{array}$ \\
\hline MAP1693c & MAP1693c & - & 15 & Peptidyl prolys-cis-trans isomerase & $\begin{array}{l}\text { Purified } \\
\text { /recombinant }\end{array}$ & ELISA pos*: $3 / 7$ pos and $0 / 3$ neg & Absent in M. bovis & Leroy et al., 2007 \\
\hline MAP2942c & MAP2942c & $m p t 53$ & 15 & Ag mpt53 & Recombinant & Immunoblot pos: 11/11 pos & $\begin{array}{l}\text { Homologous to } M . T B \text { and } M . \\
\text { bovis }\end{array}$ & Willemsen et al., 2006 \\
\hline MAP1693c & MAP1693c & - & 15.3 & $\begin{array}{l}\text { Hypothetical peptidyl-propyl cis-trans } \\
\text { isomerase }\end{array}$ & $\begin{array}{l}\text { Purified/ } \\
\text { recombinant }\end{array}$ & Immunoblot and ELISA pos & Not reported & Cho et al., 2006; Cho et al., 2007 \\
\hline MAP2411 & MAP2411 & - & 15.5 & $\begin{array}{l}\text { Hypothetical protein. Biosynthesis of } \\
\text { cofactors, prosthetic groups, and carriers: } \\
\text { Pyridoxine }\end{array}$ & Recombinant & $\begin{array}{l}\text { ELISA, no difference between infected } \\
(n=41) \text { and control sera }(n=41)\end{array}$ & Not reported & Gumber et al., 2009 \\
\hline MAP2168c & MAP2168c & - & 15.95 & Hypothetical protein & $\begin{array}{l}\text { Purified/ } \\
\text { recombinant }\end{array}$ & Immunoblot and ELISA pos & Not reported & Cho et al., 2006; Cho et al., 2007 \\
\hline GreA & MAP1027c & greA & 17.8 & Transcription elongation factor GreA & Recombinant & ELISA pos: $10 / 41$ pos and $2 / 41 \mathrm{neg}$ & Not reported & Gumber et al., 2009 \\
\hline Ppa & MAP0435c & ppa & 18.5 & $\begin{array}{l}\text { Inorganic pyrophosphatase involved in } \\
\text { metabolism }\end{array}$ & Recombinant & ELISA pos: $14 / 41$ pos and $2 / 41$ neg & Not reported & Gumber et al., 2009 \\
\hline ClpP & MAP2281c & clpP & 21.6 & $\begin{array}{l}\text { ATP-dependent Clp protease proteolytic } \\
\text { subunit. Degradation of proteins, peptides, } \\
\text { and glycopeptides }\end{array}$ & Recombinant & ELISA pos: $19 / 41$ pos and $2 / 41$ neg & Not reported & Gumber et al., 2009 \\
\hline SOD & MAP0187c & sodA & 23 & Superoxide dismutase & Purified & Not tested & Not reported & Liu et al., 2001 \\
\hline MAP3199 & MAP3199 & - & 26 & Hypothetical protein. Microtubule-associated & $\begin{array}{l}\text { Purified } \\
\text { /recombinant }\end{array}$ & ELISA pos*: $0 / 7$ pos and $0 / 3$ neg & Absent in M. bovis & Leroy et al., 2007 \\
\hline Antigen-A & - & - & 31 & Extracted from culture filtrate and sonicate & Purified & $\begin{array}{l}\text { ELISA pos: } 18 / 22 \text { pos at sp=90, AGID } \\
\text { pos } 4 / 22 \text { pos }\end{array}$ & $\begin{array}{l}\text { Similar to BCG85 complex Ag's } \\
\text { of M. bovis }\end{array}$ & Sugden et al., 1991 \\
\hline PepA & MAP3527 & рерА & 31.8 & Serine protease & $\begin{array}{l}\text { Purified/ } \\
\text { recombinant }\end{array}$ & Immunoblot and ELISA pos & Not reported & Cho et al., 2006; Cho et al., 2007 \\
\hline $32 \mathrm{kDa}$ & - & - & 32 & Fibronectin binding properties & Recombinant & Not tested & Not reported & ElZaatari et al., 1994 \\
\hline ModD & MAP1569 & $\bmod D$ & 32,3 & $\begin{array}{l}\text { Associated with MHC II and fibronectin } \\
\text { attachment }\end{array}$ & $\begin{array}{l}\text { Purified/ } \\
\text { recombinant }\end{array}$ & Immunoblot and ELISA pos & $\begin{array}{l}\text { Homologous to } M . T B \text { and } M . \\
\text { bovis }\end{array}$ & Cho et al., 2006; Cho et al., 2007 \\
\hline MAP1272c & MAP1272c & & 33.3 & Putative invasin, NlpC/P60 superfamily & Recombinant & $\begin{array}{l}\text { Immunoblot, ELISA pos: } 7 / 7 \text { pos, } 0 / 2 \\
\text { neg }\end{array}$ & $\begin{array}{l}\text { Homologous to MMP-1 of MAA } \\
\text { and M. leprae }\end{array}$ & Li et al., 2007 \\
\hline Map0210c & Map0210c & $\operatorname{pir} G$ & 34 & - & Recombinant & Immunoblot pos in $10 / 11$ & $\begin{array}{l}\text { Homologous to } M . T B \text { and } M . \\
\text { bovis }\end{array}$ & Willemsen et al., 2006 \\
\hline $\mathrm{Ag} 85 \mathrm{C}$ & MAP3531c & $f b p C 2$ & 34.1 & Putative mycolyl transferase & $\begin{array}{l}\text { Purified/ } \\
\text { recombinant }\end{array}$ & Immunoblot and ELISA pos & Highly conserved & Cho et al., 2006; Cho et al., 2007 \\
\hline MAP4308c & MAP4308c & - & 36 & Possible L-lactate-2-monooxygenase & $\begin{array}{l}\text { Purified } \\
\text { /recombinant }\end{array}$ & ELISA pos*: $4 / 7$ pos and $0 / 3$ neg & Absent in $M$. bovis & Leroy et al., 2007 \\
\hline $44,3 \mathrm{kDa}$ & - & - & 44.3 & Soluble protein & Purified & Not tested & Not reported & Mutharia et al., 1997 \\
\hline Antigen-D & - & - & 400 & $\begin{array}{l}\text { Peroxidase, extracted from culture filtrate + } \\
\text { sonicate }\end{array}$ & Purified & $\begin{array}{l}\text { ELISA pos: } 22 / 22 \text { pos at } s p=90 \text {, AGID } \\
\text { pos: } 18 / 22 \text { pos }\end{array}$ & Not reported & Sugden et al., 1991 \\
\hline Antigen-D & - & - & 400 & Proxidase & Purified & Not tested & Not reported & Brooks et al., 1991 \\
\hline $\mathrm{Ag} 85 \mathrm{~A}$ & MAP0216 & $f b p A$ & - & T-cell epitope & Purified & Not tested & Homologous to MAA & Dheenadhayalan et al., 2002 \\
\hline
\end{tabular}




\begin{tabular}{|c|c|c|c|c|c|c|}
\hline Ag85A & MAP0216 & fbpA & - & T-cell epitope & Recombinant & ELISA $\operatorname{pos}^{1}: 40 / 60$ pos, $4 / 22$ neg \\
\hline Ag85B & MAP1609c & $f b p B$ & - & T-cell epitope & Purified & Not tested \\
\hline Ag85B & MAP1609c & $f b p B$ & - & T-cell epitope & Recombinant & ELISA pos ${ }^{1}: 43 / 60$ pos, $3 / 22$ neg \\
\hline $\mathrm{Ag} 85 \mathrm{C}$ & MAP3531c & $f b p C 2$ & - & T-cell epitope & Purified & Not tested \\
\hline $\mathrm{Ag} 85 \mathrm{C}$ & MAP3531c & $f b p C 2$ & - & T-cell epitope & Recombinant & ELISA pos ${ }^{1}: 41 / 60$ pos, $4 / 18$ neg \\
\hline MAP0586c & MAP0586c & - & - & $\begin{array}{l}\text { Hypothetical protein. Possible } \\
\text { transglycosylase SLT domain }\end{array}$ & $\begin{array}{l}\text { Purified } \\
\text { /recombinant }\end{array}$ & ELISA pos*: $0 / 7$ pos and $0 / 3$ neg \\
\hline MAP2677c & MAP2677c & - & - & Hypothetical protein, glyoxylase & $\begin{array}{l}\text { Purified } \\
\text { /recombinant }\end{array}$ & ELISA pos*: $4 / 7$ pos and $0 / 3$ neg \\
\hline SOD & - & - & - & Superoxide dismutase. Induce B-cell response & recombinant & ELISA pos ${ }^{1}: 49 / 60$ pos, $2 / 22$ neg \\
\hline
\end{tabular}

Homologous to MAA

Homologous to MAA

Homologous to MAA

Homologous to MAA

Homologous to MAA

Absent in M. bovis

Absent in M. bovis

Not reported
Shin et al., 2004

Dheenadhayalan et al., 2002

Shin et al., 2004

Dheenadhayalan et al., 2002

Shin et al., 2004

Leroy et al., 2007

Leroy et al., 2007

Abbreviations: as in Table 1; MAC: Mycobacterium avium complex; MHC II: Major Histocompatibility Complex class II.

* Number of positive and negative animals extracted from available data.

${ }^{1}$ Based on available data on number of animals, specificity and sensitivity. 
Table 3. Characterized cell wall and membrane antigen candidates of Mycobacterium avium subsp. paratuberculosis

\begin{tabular}{|c|c|c|c|c|c|c|c|c|}
\hline Antigen & Locus & Gene & $\begin{array}{l}\text { Size } \\
(\text { kDa })\end{array}$ & Characteristic & Antigen & Test assay & MAP specific & Reference \\
\hline MAP1087 & MAP1087 & - & 15.4 & $\begin{array}{l}\text { Putative surface protein. Peptide/nickel } \\
\text { transport system permease }\end{array}$ & Recombinant & $\begin{array}{l}\text { Immunoblot pos: } 2 / 2 \mathrm{MAP} \text { infected } \\
\text { cattle, } 0 / 2 \text { prior to infection }\end{array}$ & $\begin{array}{l}\text { Homologous to MAA and } M \text {. } \\
\text { smegmatis }\end{array}$ & Bannantine et al., 2008a \\
\hline MAP1087 & MAP1087 & - & 15.4 & $\begin{array}{l}\text { Putative surface protein. Peptide/nickel } \\
\text { transport system permease }\end{array}$ & Recombinant & $\begin{array}{l}\text { Immunoblot: high spot intensity in } 6 / 6 \\
\text { infected cattle }\end{array}$ & $\begin{array}{l}\text { Cross-reaction with } M . \text { bovis } \\
\text { infected sera }\end{array}$ & Bannantine et al., 2008b \\
\hline $34 \mathrm{kDa}-\mathrm{C}$ & - & - & 18 & $\begin{array}{l}\text { Cell wall Ag, carboxyl termini of } 34 \mathrm{kDa} \\
\text { protein, }\end{array}$ & $\begin{array}{l}\text { Purified/ } \\
\text { recombinant }\end{array}$ & ELISA pos: $18 / 18$ pos, $0 / 50$ neg & Not reported & Malamo et al., 2006 \\
\hline MAP3968 & MAP3968 & - & 30 & $\begin{array}{l}\text { Hypothecial protein, putative heparin binding } \\
\text { hemagglutinin protein }\end{array}$ & Recombinant & ELISA pos: 9/23 pos, 4/46 neg & $92 \%$ homology to MAA & Sechi et al., 2006 \\
\hline a362 P34 & - & - & 34 & B-cell epitope (part of A36, TMA complex) & Recombinant & ELISA pos: $25 / 25$ pos, $0 / 7$ neg & $\begin{array}{l}\text { Homologous to } M \text {. leprae, but } \\
\text { two species specific epitopes }\end{array}$ & Dekesel et al., 1993 \\
\hline P34 & - & - & 34 & B-cell epitope (part of A36, TMA complex) & Purified & Not tested & $\begin{array}{l}\text { Specific based on EMBL data } \\
\text { bank }\end{array}$ & Gilot et al., 1993 \\
\hline P34-p5 & - & - & 34 & B-cell epitope peptide A & Recombinant & ELISA pos: $6 / 10$ pos, $0 / 10$ neg & $\begin{array}{l}\text { Cross-reaction with } M \text {. bovis } \\
\text { infected sera }(0 / 6)\end{array}$ & Ostrowski et al., 2003 \\
\hline P34-p8 & - & - & 34 & B-cell epitope peptide B & Recombinant & ELISA pos: $8 / 10$ pos, $0 / 10$ neg & $\begin{array}{l}\text { Cross-reaction with } M . \text { bovis } \\
\text { infected sera }(0 / 6)\end{array}$ & Ostrowski et al., 2003 \\
\hline $34 \mathrm{kDa}$ & - & - & 34 & B-cell epitope (part of A36, TMA complex) & Purified & $\begin{array}{l}\text { Immunoblot: high spot intensity in } 3 / 3 \\
\text { infected cattle }\end{array}$ & $\begin{array}{l}\text { Low cross-reaction with MAA, } \\
\text { M. bovis and } M . \text { phlei }\end{array}$ & Dekesel et al., 1992 \\
\hline MAP2121c & MAP2121c & - & 35 & $\begin{array}{l}\text { Major membrane protein I, putative role in } \\
\text { invasion of epithelial cells }\end{array}$ & Recombinant & $\begin{array}{l}\text { Immunoblot: high spot intensity in pos } \\
\text { rabbit and mouse, low in } 5 / 5 \text { pos cattle }\end{array}$ & Homologous to M. leprae & Bannantine et al., 2008d \\
\hline P35 & - & - & 35 & - & Recombinant & $\begin{array}{l}\text { Immunoblot reaction with anti-MAP } \\
\text { rabbit serum and skin reaction in } \\
\text { guinea pigs }\end{array}$ & $\begin{array}{l}\text { Cross-reaction with MAA in skin } \\
\text { test }\end{array}$ & Basagoudanavar et al., 2004 \\
\hline MMP & - & - & 35 & $\begin{array}{l}\text { T-cell Ag (homologous to major membrane } \\
\text { protein, MMP) }\end{array}$ & - & Not tested & $\begin{array}{l}\text { Homologous to M. leprae and } \\
\text { MAA }\end{array}$ & Banasure et al., 2001 \\
\hline MMP & - & - & 35 & $\begin{array}{l}\text { Major membrane protein. Role in invasion of } \\
\text { epithelial cells. }\end{array}$ & Recombinant & Not tested & $\begin{array}{l}\text { Homologous to M. leprae and } \\
\text { MAA }\end{array}$ & Bannantine et al., 2003 \\
\hline TMA & - & - & 100 & Cytoplasmic protein of TMA complex & Purified & $\begin{array}{l}\text { Not tested, comparison of TMA from } \\
\text { MAP, MAA and M. bovis }\end{array}$ & $\begin{array}{l}\text { Homologues in MAA and } M \text {. } \\
\text { bovis }\end{array}$ & Bruneteau et al., 1992 \\
\hline a362 & - & - & - & $\begin{array}{l}\mathrm{Ag} \text { containing B-cell epitope. Polypeptide of } \\
\text { carboxyl termini of } 34 \mathrm{kDa} \text { protein }\end{array}$ & Recombinant & $\begin{array}{l}\text { ELISA pos': } 84 / 208 \text { pos, } 9 / 175 \mathrm{neg}, \\
\text { 2/38 M. bovis pos }\end{array}$ & $\begin{array}{l}\text { Specific compared to MAA, } M \\
\text { bovis and } M \text {. phlei. Low cross- } \\
\text { reaction with } M \text {. bovis }\end{array}$ & Vannuffel et al., 1994 \\
\hline MAP1204 & MAP1204 & - & - & Hypothetical protein, putative invasin & Recombinant & $\begin{array}{l}\text { Immunoblot: high spot intensity in } 6 / 6 \\
\text { infected cattle }\end{array}$ & $\begin{array}{l}\text { Cross-reaction with } M . \text { bovis } \\
\text { cow sera }\end{array}$ & Bannantine et al., 2008b \\
\hline MAP1506 & MAP1506 & - & & Hypothetical protein, PPE protein family & $\begin{array}{l}\text { Purified } \\
\text { peptide }\end{array}$ & Not tested & $\begin{array}{l}\text { Homologous in } M \text {. avium subsp. } \\
\text { hominissuis and MAA }\end{array}$ & Newton et al., 2009 \\
\hline MAP3817c & MAP3817c & - & & Putative membrane protein & Recombinant & $\begin{array}{l}\text { Immunoblot: high spot intensity in } 5 / 5 \\
\text { pos cattle }\end{array}$ & Sequence unique to MAP & Bannantine et al., 2008d \\
\hline MAP3420c & MAP3420c & - & - & Hypothetical protein, PPE protein family & $\begin{array}{l}\text { Purified/ } \\
\text { recombinant }\end{array}$ & $\begin{array}{l}\text { Immunoblot pos*: } 4 / 4 \mathrm{FC} \text { pos, } 0 / 4 \mathrm{FC} \\
\text { neg; } 3 / 4 \text { tissue pos, } 1 / 3 \text { tissue neg. } \\
\text { ELISA pos: } 1 \text { pos in all } 3 \text { ELISA/4 FC } \\
\text { pos. }\end{array}$ & $\begin{array}{l}\text { Homologous in M. avium subsp. } \\
\text { hominissuis and MAA }\end{array}$ & Newton et al., 2009 \\
\hline rcP34 & - & - & - & Carboxyl termini of $34 \mathrm{kDa}$ protein & Recombinant & Production of monoclonal antibodies & $\begin{array}{l}\text { Common epitopes of MAP, } \\
\text { MAA and } M \text {. intracellulare }\end{array}$ & Malamo et al., 2007 \\
\hline
\end{tabular}

Abbreviations: as in Table 1

*Number of positive and negative animals extracted from available data.

${ }^{1}$ Based on available data on number of animals, specificity and sensitivity. 
Table 4. Characterized lipoprotein antigen candidates of Mycobacterium avium subsp. paratuberculosis

\begin{tabular}{|c|c|c|c|c|c|c|c|c|}
\hline Antigen & Locus & Gene & $\begin{array}{l}\text { Size } \\
(\mathrm{kDa})\end{array}$ & Characteristic & Antigen & Test assay & MAP specific & Reference \\
\hline Lpp34 & - & - & 20.8 & Putative lipoprotein & Recombinant & $\begin{array}{l}\text { Immunoblot pos: } \\
48 \text { pos, } 3 \text { neg and } 7 \text { doubtful of } 23 \text { pos, } \\
\text { and } 35 \text { neg cattle }\end{array}$ & $\begin{array}{l}\text { Homologous to MAA and E. coli, } \\
\text { but absent in } M . T B \text { complex }\end{array}$ & Gioffre et al., 2006 \\
\hline L5P & - & - & - & Lipopentapeptide, a non-ribosomal synthase & Purified & $\begin{array}{l}\text { ELISA pos: } 2 / 2 \text { pos goats, } 3 / 3 \text { pos cattle, } \\
0 / 3 \text { experimental infected mouse/cattle }\end{array}$ & $\begin{array}{l}\text { Not present in MAA or } M \text {. } \\
\text { smegmatis. }\end{array}$ & Biet et al., 2008 \\
\hline LAM & - & - & - & Lipoarabinomannan & Purified & AGID pos: $1 / 1$ pos & Not reported & Sugden et al., 1987 \\
\hline Para-LP-01 & - & - & - & $\begin{array}{l}\text { Cell wall lipopeptide, likely major component } \\
\text { of outer part of cell envelope }\end{array}$ & Purified & ELISA pos*: $5 / 6$ pos, $0 / 3$ neg & Not present in MAA & Eckstein et al., 2006 \\
\hline Polar GPL-1 & - & - & - & $\begin{array}{l}\text { Glycopeptidolipid, belongs to polar mycoside } \\
\text { C glycopeptidolipid family }\end{array}$ & Purified & ELISA pos: 1 (high)/9 pos, $0 /(?)$ neg & Not reported & $\begin{array}{l}\text { Camphausen et al., } \\
1985\end{array}$ \\
\hline PstA & - & pstA & - & $\begin{array}{l}\text { Cell wall lipopeptide, maybe involved in GLP- } \\
\text { biosynthesis and biofilm formation }\end{array}$ & Recombinant & Peptides tested in immunoblot & Present in MAA & Wu et al., 2009 \\
\hline
\end{tabular}

Abbreviations: as in Table 1.

*Number of positive and negative animals extracted from available data 
Table 5. Characterized heat shock antigen candidates of Mycobacterium avium subsp. paratuberculosis

\begin{tabular}{|c|c|c|c|c|c|c|c|c|}
\hline Antigen & Locus & Gene & $\begin{array}{l}\text { Size } \\
(\text { kDa })\end{array}$ & Characteristic & Antigen & Test assay & MAP specific & Reference \\
\hline GroES & MAP4264 & GroES & 10 & - & Recombinant & Not tested & $\begin{array}{l}\text { Identical to MAA and homologous } \\
\text { to other mycobacteria }\end{array}$ & $\begin{array}{l}\text { Cobb and Frothingham, } \\
1999\end{array}$ \\
\hline MAP3841 & MAP3841 & grpE & 23.7 & - & Recombinant & $\begin{array}{l}\text { ELISA pos*: } 4 / 6 \text { pos, Dot blot neg, } \\
\text { Western blot pos }\end{array}$ & Higher expression in MAP>MAA & Hughes et al., 2008 \\
\hline Hsp65K & - & - & 65 & Member of GroEL family & Recombinant & $\begin{array}{l}\text { Immunoblot reaction with rabbit anti- } \\
\text { MAP serum }\end{array}$ & Homologous to other mycobacteria & ElZaatari et al., 1994 \\
\hline Hsp65K & & - & 65 & Member of GroEL family & Recombinant & $\begin{array}{l}\text { Immunoblot pos*: } 8 / 35 \text { pos cattle, } 2 / 2 \\
\text { pos sheep, } 1 / 2 \text { pos goats, } 0 / 10 \text { neg cattle }\end{array}$ & $\begin{array}{l}\text { Homologous to } M . T B, \text { M. leprae, } \\
\text { MAA }\end{array}$ & ElZaatari et al., 1995 \\
\hline Hsp70 & - & - & 70 & Interaction with bovine antigen presenting cells & Recombinant & Not tested. Investigation of mechanisms & Not reported & Langelaar et al., 2002 \\
\hline MAP3840 & MAP3840 & dnaK & 70 & $\begin{array}{l}\text { Molecular chaperone, protein folding and } \\
\text { stabilization }\end{array}$ & Recombinant & $\begin{array}{l}\text { Immunoblot: high spot intensity in pos } \\
\text { rabbit and mouse, high in } 3 / 5 \text { pos cattle, } \\
\text { low } 2 / 5 \text { pos cattle }\end{array}$ & Not reported & $\begin{array}{l}\text { Bannantine et al., 2007; } \\
\text { Bannantine et al., 2008d }\end{array}$ \\
\hline
\end{tabular}

Abbreviations: as in Table 1.

*Number of positive and negative animals extracted from available data 
Table 6. Characterized hypothetical proteins, antigen candidates of unknown function or other antigen candidates of Mycobacterium avium subsp. paratuberculosis

\begin{tabular}{|c|c|c|c|c|c|c|c|c|}
\hline Antigen & Locus & Gene & $\begin{array}{l}\text { Size } \\
(\mathrm{kDa})\end{array}$ & Characteristic & Antigen & Test assay & MAP specific & Reference \\
\hline MAP3155c & MAP3155c & - & 9 & - & Recombinant & $\begin{array}{l}\text { Immunoblot: high spot intensity in } 5 / 5 \\
\text { pos cattle, high in pos rabbit and low in } \\
\text { pos mouse }\end{array}$ & Not reported & Bannantine et al., 2008d \\
\hline $\operatorname{Ag} 6$ & $\begin{array}{l}\text { Overlap } \\
\text { MAP0864 } \\
\text { and } \\
\text { MAP0865 }\end{array}$ & - & 16 & T-cell epitope, putative protein & Recombinant & ELISA pos*: $8 / 18$ pos, $1 / 48$ neg & $\begin{array}{l}\text { Specific compared to MAA. Low } \\
\text { cross-reaction with } M \text {. bovis (1/48) }\end{array}$ & Leroy et al., 2009 \\
\hline MAP3857 & MAP3857 & итрA & 18.7 & $\begin{array}{l}\text { UmpA (orotate phosphoribosyltransferase), } \\
\text { biosynthesis }\end{array}$ & Recombinant & $\begin{array}{l}\text { ELISA pos* in } 0 / 6 \text { pos, Dot blot pos, } \\
\text { Western blot neg }\end{array}$ & Higher expression in MAP $>$ MAA & Hughes et al., 2008 \\
\hline $21 \mathrm{~K}$ & - & - & 21 & Unknown function & Recombinant & Not tested & Not reported & ElZaatari et al., 1994 \\
\hline MAP2685 & MAP2685 & - & 21.3 & Hypothetical conserved protein & Recombinant & $\begin{array}{l}\text { ELISA pos*: in } 6 / 6 \text { pos, Dot blot pos, } \\
\text { Western blot pos }\end{array}$ & Higher expression in MAP $>$ MAA & Hughes et al., 2008 \\
\hline Ag5 & - & - & 22.5 & T-cell epitope, putative protein & Recombinant & ELISA pos*: 5/18 pos, $1 / 48$ neg & $\begin{array}{l}\text { Specific compared to MAA. Low } \\
\text { cross-reaction with } M \text {. bovis (1/48) }\end{array}$ & Leroy et al., 2009 \\
\hline MAP1564c & MAP1564c & - & 23.1 & Short chain dehydrogenase & Recombinant & $\begin{array}{l}\text { ELISA pos*: } 6 / 6 \text { pos, Dot blot pos, } \\
\text { Western blot pos }\end{array}$ & Higher expression in MAP>MAA & Hughes et al., 2008 \\
\hline MAP3627 & MAP3627 & - & 23.1 & Hypothetical protein involved in metabolism & Recombinant & $\begin{array}{l}\text { ELISA pos*: } 6 / 6 \text { pos, Dot blot neg, } \\
\text { Western blot pos }\end{array}$ & Higher expression in MAP $>$ MAA & Hughes et al., 2008 \\
\hline MAP0268c & MAP0268c & - & 23.8 & Hypothetical conserved protein & Recombinant & $\begin{array}{l}\text { ELISA pos*: 0/6 pos, Dot blot pos, } \\
\text { Western blot pos }\end{array}$ & Higher expression in MAP>MAA & Hughes et al., 2008 \\
\hline MAP3491 & MAP3491 & - & 25.2 & Hypothetical hydrolase & Recombinant & $\begin{array}{l}\text { ELISA pos*: } 6 / 6 \text { pos, Dot blot pos, } \\
\text { Western blot neg }\end{array}$ & Higher expression in MAP $>$ MAA & Hughes et al., 2008 \\
\hline MAP1204 & MAP1204 & - & 25.4 & Putative exported p60 protein, virulence factor & Recombinant & $\begin{array}{l}\text { Immunoblot pos: } 2 / 2 \text { infected cattle, } 0 / 2 \\
\text { prior infection }\end{array}$ & Present in MAA and $M$. smegmatis & Bannantine et al., 2008a \\
\hline MAP1297 & MAP1297 & hisA & 25.4 & HisA (phosphoribosyl isomerise) & Recombinant & $\begin{array}{l}\text { ELISA pos*: } 0 / 6 \text { pos, Dot blot pos, } \\
\text { Western blot pos }\end{array}$ & Higher expression in MAP $>$ MAA & Hughes et al., 2008 \\
\hline MAP2878c & MAP2878c & dapB & 25.6 & $\begin{array}{l}\text { DapB (dihydrodipicolinate reductase), amino } \\
\text { acid biosynthesis }\end{array}$ & Recombinant & $\begin{array}{l}\text { ELISA pos*: } 5 / 6 \text { pos, Dot blot pos, } \\
\text { Western blot neg }\end{array}$ & Higher expression in MAP>MAA & Hughes et al., 2008 \\
\hline MAP0865 & MAP0865 & - & 30.9 & Hypothetical protein & Recombinant & $\begin{array}{l}\text { ELISA*: } 3 / 3 \text { sheep anti-MAP sera } \\
\text { recognised antigen }\end{array}$ & Unique to MAP & Bannantine et al., 2008c \\
\hline MAP1365 & MAP1365 & $\operatorname{ardF}$ & 33.6 & $\operatorname{ArgF}$ (ornithine carbamoyltransferase ) & Recombinant & $\begin{array}{l}\text { ELISA pos*: } 5 / 6 \text { pos, Dot blot pos, } \\
\text { Western blot pos }\end{array}$ & Higher expression in MAP $>$ MAA & Hughes et al., 2008 \\
\hline $34 \mathrm{kDa}$ & - & - & 34 & Putative serine protease & Purified & $\begin{array}{l}\text { Immunoblot pos: } 8 / 14 \text { pos sheep, } 2 / 2 \\
\text { pos goats, } 3 / 3 \text { deer }\end{array}$ & Homologous to a number of bacteria & Cameron et al., 1994 \\
\hline $34.5 \mathrm{kDa}$ & - & - & 34.5 & Cytoplasmic protein & Purified & Not tested & $\begin{array}{l}\text { Cross-reaction with tested } \\
\text { mycobacteria }\end{array}$ & Mutharia et al., 1997 \\
\hline MAP0334 & MAP0334 & - & 34.5 & - & Recombinant & $\begin{array}{l}\text { ELISA pos*: } 6 / 6 \text { pos, Dot blot pos, } \\
\text { Western blot pos }\end{array}$ & Higher expression in MAP $>$ MAA & Hughes et al., 2008 \\
\hline P35 & - & - & 35 & - & Recombinant & $\begin{array}{l}\text { Immunoblot pos: } 31 / 36 \text { pos } \\
\text { sheep/goats/cows, } 0 / 3 \mathrm{M} \text {. bovis infected, } \\
0 / 3 \text { inoculated cows, } 0 / 15 \text { healthy } \\
\text { controls }\end{array}$ & $\begin{array}{l}\text { Cross-reaction with anti-M. bovis } \\
\text { and anti-MAA serum }\end{array}$ & ElZaatari et al., 1997 \\
\hline $35 \mathrm{kDa}$ & - & - & 35 & - & Recombinant & ELISA pos ${ }^{1}: 56 / 60$ pos, $3 / 22$ neg & Not reported & Shin et al., 2004 \\
\hline MAP1012c & MAP1012c & - & 37.5 & - & Recombinant & $\begin{array}{l}\text { ELISA pos*: } 6 / 6 \text { pos, Dot blot pos, } \\
\text { Western blot pos }\end{array}$ & Higher expression in MAP $>$ MAA & Hughes et al., 2008 \\
\hline $\mathrm{Ag} 7$ & MAP1637c & - & 40 & $\begin{array}{l}\text { T-cell epitope. Biosynthesis of cofactors, } \\
\text { prosthetic groups, and carriers }\end{array}$ & Recombinant & ELISA pos*: $12 / 18$ pos, $1 / 48$ neg & $\begin{array}{l}\text { Specific compared to MAA. Low } \\
\text { cross-reaction with } M \text {. bovis }(1 / 48)\end{array}$ & Leroy et al., 2009 \\
\hline
\end{tabular}




\begin{tabular}{|c|c|c|c|c|c|c|c|c|}
\hline MAP3932c & MAP3932c & mоан3 & 41.4 & $\begin{array}{l}\text { MoaA3 (molybdopterin biosynthesis protein } \\
\text { MoeA). Biosynthesis of cofactors, prosthetic } \\
\text { groups and carriers }\end{array}$ & Recombinant & $\begin{array}{l}\text { ELISA pos*: } 0 / 6 \text { pos, Dot blot pos, } \\
\text { Western blot pos }\end{array}$ & Higher expression in MAP $>$ MAA & Hughes et al., 2008 \\
\hline MAP3175c & MAP3175c & $\operatorname{prf} B$ & 41.5 & Peptide chain release factor 2 , protein synthesis & Recombinant & $\begin{array}{l}\text { ELISA pos*: } 0 / 6 \text { pos, Dot blot pos, } \\
\text { Western blot pos }\end{array}$ & Higher expression in MAP $>$ MAA & Hughes et al., 2008 \\
\hline $42 \mathrm{kDa}$ & - & - & 42 & Cytoplasmic protein & Purified & Not tested & Higher expression in MAP>MAA & White et al., 1994 \\
\hline MAP4147 & MAP4147 & - & 42.2 & $\begin{array}{l}\text { Hypothecial protein involved in energy } \\
\text { metabolism, electron transport }\end{array}$ & Recombinant & $\begin{array}{l}\text { ELISA pos*: } 0 / 6 \text { pos, Dot blot pos, } \\
\text { Western blot pos }\end{array}$ & Higher expression in MAP $>$ MAA & Hughes et al., 2008 \\
\hline MAP3457 & MAP3457 & metC & 47.6 & $\begin{array}{l}\text { MetC(o-acetylhomoserine } \\
\text { aminocarboxypropyltransferase) involved in } \\
\text { metabolism }\end{array}$ & Recombinant & $\begin{array}{l}\text { ELISA pos*: } 0 / 6 \text { pos, Dot blot neg, } \\
\text { Western blot pos }\end{array}$ & Higher expression in MAP>MAA & Hughes et al., 2008 \\
\hline MAP1293 & MAP1293 & hisD & 49.4 & HisD (histidinol dehydrogenase) & Recombinant & $\begin{array}{l}\text { ELISA pos*: } 0 / 6 \text { pos, Dot blot pos, } \\
\text { Western blot pos }\end{array}$ & Higher expression in MAP $>$ MAA & Hughes et al., 2008 \\
\hline MAP0860 & MAP0860 & & - & - & Recombinant & $\begin{array}{l}\text { Immunoblot pos: } 0 / 1 \text { pos mouse, } 0 / 2 \text { pos } \\
\text { rabbit and } 0 / 2 \text { pos cattle }\end{array}$ & Unique to MAP & Paustian et al., 2004 \\
\hline MAP0860c & MAP0860c & - & - & - & Recombinant & $\begin{array}{l}\text { Immunoblot: high spot intensity in } 5 / 5 \\
\text { pos cattle, high in pos rabbit and low in } \\
\text { pos mouse }\end{array}$ & Unique to MAP & Bannantine et al., 2008d \\
\hline MAP0862 & MAP0862 & & - & - & Recombinant & $\begin{array}{l}\text { Immunoblot pos: } 1 / 1 \text { pos mouse, } 2 / 2 \text { pos } \\
\text { rabbit and } 2 / 2 \text { pos cattle }\end{array}$ & Unique to MAP & Paustian et al., 2004 \\
\hline MAP0862 & MAP0862 & - & - & - & Recombinant & $\begin{array}{l}\text { ELISA pos: } 9 / 11 \text { pos. ELISA*: } 3 / 3 \\
\text { sheep anti-MAP sera recognised antigen }\end{array}$ & Unique to MAP & Bannantine et al., 2008c \\
\hline MAP1643 & MAP1643 & $a c e A B$ & - & Putative isocitrate lyase & Recombinant & Not tested & Not reported & Bannantine et al., 2007 \\
\hline MAP1730c & MAP1730c & - & & - & Recombinant & $\begin{array}{l}\text { Immunoblot: high spot intensity in } 6 / 6 \\
\text { infected cattle }\end{array}$ & $\begin{array}{l}\text { Cross reaction with } M \text {. bovis cow } \\
\text { sera }\end{array}$ & Bannantine et al., 2008b \\
\hline MAP2154c & MAP2154c & & - & - & Recombinant & $\begin{array}{l}\text { Immunoblot pos: } 1 / 1 \text { pos mouse, } 1 / 2 \text { pos } \\
\text { rabbit and } 0 / 2 \text { pos cattle }\end{array}$ & Unique to MAP & Paustian et al., 2004 \\
\hline MAP2182c & MAP2182c & - & - & Hypothetical conserved protein & Recombinant & $\begin{array}{l}\text { Immunoblot: high spot intensity in } 4 / 5 \\
\text { pos cattle, high in pos mouse and rabbit }\end{array}$ & Highly conserved protein & Bannantine et al., 2008d \\
\hline MAP2963c & MAP2963c & - & - & $\begin{array}{l}\text { Hypothetical conserved protein containing } \\
\text { heme binding domain }\end{array}$ & Recombinant & $\begin{array}{l}\text { Immunoblot pos: } 1 / 1 \text { pos mouse, } 2 / 2 \text { pos } \\
\text { rabbit and } 2 / 2 \text { pos cattle }\end{array}$ & Unique to MAP & Paustian et al., 2004 \\
\hline MAP3732c & MAP3732c & - & - & & Recombinant & $\begin{array}{l}\text { Immunoblot pos: } 1 / 1 \text { pos mouse, } 2 / 2 \text { pos } \\
\text { rabbit and } 2 / 2 \text { pos cattle }\end{array}$ & Unique to MAP & Paustian et al., 2004 \\
\hline MAP-antigen & 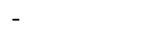 & - & $-i$ & Protoplasmic antigen & Purified & ELISA pos: 50/60 pos, 5/44 neg cattle & Cross-reaction with several bacteria & Abbas et al., 1983 \\
\hline MBP-gene56 & & & - & $\begin{array}{l}\text { Protein of unknown function produced by } \\
\text { MAP (selected in Bannantine et al., 2002) }\end{array}$ & Recombinant & Immunoblot pos: $5 / 6$ pos, $0 / 4$ neg cattle & $\begin{array}{l}\text { Specific compared to } 9 \text { mycobacteria } \\
\text { species }\end{array}$ & Bannantine et al., 2004 \\
\hline MBP-gene135 & & & & $\begin{array}{l}\text { Protein of unknown function produced by } \\
\text { MAP (selected in Bannantine et al., 2002) }\end{array}$ & Recombinant & $\begin{array}{l}\text { Immunoblot pos: } 4 / 6 \text { pos } \\
1 / 4 \text { neg cattle }\end{array}$ & $\begin{array}{l}\text { Specific compared to } 9 \text { mycobacteria } \\
\text { species }\end{array}$ & Bannantine et al., 2004 \\
\hline MBP-gene218 & & & - & $\begin{array}{l}\text { Protein of unknown function produced by } \\
\text { MAP (selected in Bannantine et al., 2002) }\end{array}$ & Recombinant & Immunoblot pos: $5 / 6$ pos, $0 / 4$ neg cattle & $\begin{array}{l}\text { Specific compared to } 9 \text { mycobacteria } \\
\text { species }\end{array}$ & Bannantine et al., 2004 \\
\hline MBP-gene241 & & & - & $\begin{array}{l}\text { Protein of unknown function produced by } \\
\text { MAP (selected in Bannantine et al., 2002) }\end{array}$ & Recombinant & Immunoblot pos: $6 / 6$ pos, $1 / 4$ neg cattle & $\begin{array}{l}\text { Specific compared to } 9 \text { mycobacteria } \\
\text { species }\end{array}$ & Bannantine et al., 2004 \\
\hline MBP-gene254 & & & - & $\begin{array}{l}\text { Protein of unknown function produced by } \\
\text { MAP (selected in Bannantine et al., 2002) }\end{array}$ & Recombinant & Immunoblot pos: $5 / 6$ pos, $4 / 6$ neg cattle & $\begin{array}{l}\text { Specific compared to } 9 \text { mycobacteria } \\
\text { species }\end{array}$ & Bannantine et al., 2004 \\
\hline
\end{tabular}

Abbreviation: as in Table 1.

*Number of positive and negative animals extracted from available data. 